\title{
From mono- to bivalent: improving theranostic properties of target modules for redirection of UniCAR T cells against EGFR- expressing tumor cells in vitro and in vivo
}

\author{
Susann Albert ${ }^{1, *}$, Claudia Arndt ${ }^{2, *}$, Stefanie Koristka ${ }^{2}$, Nicole Berndt ${ }^{3}$, Ralf \\ Bergmann', Anja Feldmann², Marc Schmitz ${ }^{3,4,5}$, Jens Pietzsch ${ }^{2,6}$, Jörg Steinbach ${ }^{2,5,6}$ \\ and Michael Bachmann ${ }^{1,2,3,5}$ \\ ${ }^{1}$ UniversityCancerCenter (UCC) Dresden, Tumor Immunology, 'Carl Gustav Carus' Technische Universität Dresden, Dresden, \\ Germany \\ ${ }^{2}$ Helmholtz-Zentrum Dresden-Rossendorf (HZDR), Institute of Radiopharmaceutical Cancer Research, Dresden, Germany \\ ${ }^{3}$ German Cancer Consortium (DKTK), part \ner site Dresden and German Cancer Research Center (DKFZ), Heidelberg, \\ Germany \\ ${ }^{4}$ Institute of Immunology, Medical Faculty, 'Carl Gustav Carus' Technische Universität Dresden, Dresden, Germany \\ ${ }^{5}$ National Center for Tumor Diseases (NCT), partner site Dresden, Dresden, Germany \\ ${ }^{6}$ Faculty of Chemistry and Food Chemistry, School of Science, Technische Universität Dresden, Germany \\ "These authors contributed equally to this work \\ Correspondence to: Michael Bachmann, email: m.bachmann@hzdr.de \\ Keywords: CAR T cell immunotherapy; solid epithelial tumor; nanobody; affinity; PET imaging \\ Received: January 22, $2018 \quad$ Accepted: April 28, $2018 \quad$ Published: May 22, 2018 \\ Copyright: Albert et al. This is an open-access article distributed under the terms of the Creative Commons Attribution License 3.0 \\ (CC BY 3.0), which permits unrestricted use, distribution, and reproduction in any medium, provided the original author and source \\ are credited.
}

\section{ABSTRACT}

CAR-modified T cells show impressive results in clinical trials. However, cytokine release syndrome and "on-target, off-tumor" reactions represent most concerning side effects. To improve the safety of CAR-T cell therapy, we established a switchable CAR platform termed UniCAR system consisting of two components: UniCAR-modified $T$ cells and tumor-specific target modules (TM). For treatment of EGFR ${ }^{+}$epithelial tumors, we recently described a monovalent nanobody-based a-EGFR TM, either expressed in bacteria or eukaryotic cells. In spite of the identical primary sequence the eukaryotic TM showed a reduced killing capability and affinity. Here we describe a novel bivalent a-EGFR-EGFR TM. As expected, the avidity of the bivalent TM is higher than that of its monovalent counterpart. Binding of neither the monovalent a-EGFR TM nor the bivalent a-EGFR-EGFR TM to EGFR effected the EGF-mediated signaling. While the monovalent a-EGFR TM could only mediate the killing of tumor cells expressing high levels of EGFR, the bivalent a-EGFR-EGFR TM could redirect UniCAR T cells to tumor cells expressing low levels of EGFR. According to PET experiments in vivo, the increased avidity of the bivalent a-EGFR-EGFR TM improves the enrichment at the tumor site and its use for PET imaging.

\section{INTRODUCTION}

The epidermal growth factor receptor (EGFR) is a ubiquitously expressed transmembrane protein of the HER family of tyrosine kinase receptors that plays a central role for normal cell and organ development [1-3]. Ligand binding activates downstream signaling cascades involved in controlling cell proliferation and differentiation, apoptosis, cell migration as well as angiogenesis [4-6]. Even minor disruptions in the EGFR signaling pathway can promote tumor growth [3]. Hence, many cancers of epithelial origin, e.g. head and neck, colorectal and 
lung tumors, are characterized by EGFR overexpression $[1-3,7]$ or mutated EGFR forms [3, 8, 9]. High EGFR expression level correlates with poor prognosis [10] and an increased resistance to chemotherapy and radiation [1115]. This underlines the potential of EGFR as a promising target for cancer immunotherapy. Within the last two decades, many EGFR-targeted therapies have emerged. These include tyrosine kinase inhibitors (Erlotinib, Gefitinib, Afatinib) and $\alpha$-EGFR monoclonal antibodies (Cetuximab, Panitumumab, Necitumumab) approved for treatment of metastatic colorectal cancer, head and neck cancer, pancreatic cancer and lung cancer [3, 16-18]. Nonetheless, as learned from both preclinical and clinical studies therapeutic approaches are often accompanied by mild to severe side effects due to the widespread EGFR expression on healthy tissues $[19,20]$. This clearly emphasizes the urgent need for a more precise control of highly effective EGFR directed cancer treatments.

Recently, we described the modular UniCAR platform technology for retargeting of $\mathrm{T}$ cells to various tumor-associated surface antigens (TAAs) including EGFR that meets this criterion [21-27]. It represents a unique chimeric antigen receptor (CAR) T cell therapy combining $\mathrm{T}$ cells engrafted with a universal CAR (UniCAR) and an antibody (Ab)-based component referred to as target module (TM) (Figure 1). Like conventional CARs [28, 29], the UniCAR construct consists of an extracellular $\mathrm{Ab}$-derived binding moiety, a transmembrane domain and intracellular activation motifs derived from $\mathrm{CD} 3 \zeta$ and CD28 for signal transduction. In contrast to CARs, the extracellular binding domain of UniCARs does not recognize a certain TAA on tumor cells but the short peptide epitope E5B9 (UniCAR epitope) used to tag the TM. Thus, UniCAR-modified T cells are per se inactive. The TM in turn confers the UniCAR system its tumor specificity. Due to its composition of a binding moiety for a TAA and the E5B9-tag it acts as a key link between UniCAR-armed $\mathrm{T}$ cells and target-positive cancer cells (Figure 1). Despite this modular character, tumor cell elimination is mediated with a high specificity and effectiveness similar to conventional CAR approaches [e.g. 24]. Beyond that, after infusion of UniCAR-engrafted $\mathrm{T}$ cells into patients effector mechanisms are only turned on by administration of tumor-specific TMs and inversely turned off by interruption of TM supply, which represents the main advantage of the UniCAR system. It provides an important self-limiting safety switch to quickly reduce or control critical side effects often accompanied by conventional CAR T cell therapies: (I) cytokine release syndrome (CRS) as a result of excessive "on-target, ontumor" toxicity [30-32] and (II) elimination of healthy cells due to uncontrollable "on-target, off-tumor" effects [31-33]. Currently, alleviation of these partly lifethreatening side effects requires further treatment with other immunomodulating drugs including corticosteroids, interleukin-6 receptor blockade (Tocilizumab) and immunoglobulins [31, 32, 34, 35]. This should not be necessary using the UniCAR system as it enables a direct and precise control of $\mathrm{T}$ cell activity.

Considering that EGFR is a widespread tumor marker also expressed on normal epithelial cells, the UniCAR technology might be an appropriate solution for efficient EGFR-targeted therapy that simultaneously provides the necessary control mechanisms. As proofof-concept, we recently reported on UniCAR-armed $\mathrm{T}$ cells successfully redirected to $\mathrm{EGFR}^{+}$tumors in vitro and in vivo via a novel nanobody $(\mathrm{Nb})$-based $\alpha$-EGFR TM expressed in $E$. coli (termed $\alpha$-EGFR TM (pro)) or eukaryotic CHO cells (termed $\alpha$-EGFR TM) [23]. Pharmacokinetic studies in immunodeficient mice revealed that TMs can be released from UniCAR-TM complexes and thereby support the idea of the on/offswitchable UniCAR system. For an unknown reason, the $\alpha$-EGFR TM (pro) showed not only an overall enhanced functionality in comparison to the eukaryotic one but also a higher affinity. We therefore asked whether or not we can further improve the effectiveness of $\alpha$-EGFR TMs by increasing their binding affinity. To answer this question, we constructed a novel bivalent $\alpha$-EGFR-EGFR TM by fusion of two $\alpha$-EGFR Nb domains via the E5B9tag. After expression in $\mathrm{CHO}$ cells, its binding avidity, potential EGFR-mediated signaling effects, anti-tumor efficiency and pharmacokinetic behavior were compared to the previously described monovalent $\alpha$-EGFR TM.

Here we report that the enhanced avidity of the bivalent $\alpha$-EGFR-EGFR TM improves both its killing capability and its use as PET tracer. Neither the monovalent nor the bivalent TM mediates EGFR signaling under retargeting conditions. We also show that the binding capability of the TM in combination with the density of EGFR on the tumor cell decides whether or not UniCAR T cells will attack the target cell.

\section{RESULTS}

\section{Establishment of a novel bivalent EGFR-specific TM}

For arming the modular UniCAR platform, we established a novel bivalent TM for redirection of UniCAR $\mathrm{T}$ cells against $\mathrm{EGFR}^{+}$carcinoma cells (Figure 1). So far, a monovalent $\alpha$-EGFR TM has been successfully generated and characterized [23]. However, the chosen expression system (eukaryotic vs. prokaryotic) influenced its affinity and functionality within the UniCAR system [23]. To elucidate whether TM functionality can be further improved by an increase in affinity, we here performed comparative analyses between monovalent and bivalent EGFR-specific TMs both expressed in CHO cells.

As schematically summarized in Figure 2A, the bivalent $\alpha$-EGFR-EGFR TM was generated by flanking the UniCAR epitope with one EGFR-specific camelid 
Nb-domain (clone 7C12) [36] on each side. The recently described monovalent $\alpha$-EGFR TM contains only one $\mathrm{Nb}$-domain C-terminally equipped with the UniCAR epitope. At the N-terminus, both TMs contain the same signal peptide for triggering secretion into cell culture supernatant. They further comprise a C-terminal histidine (His ${ }_{6}$ )-tag for protein purification and detection. The different domains of the recombinant $\mathrm{Ab}$ molecules were fused via flexible peptide linkers consisting of glycine and serine residues $\left(\mathrm{G}_{4} \mathrm{~S}\right)$.

After expression by a permanent $\mathrm{Ab}$-producing $\mathrm{CHO}$ cell line the recombinant proteins were isolated from cell culture supernatant via Ni-NTA affinity chromatography. For biochemical characterization, the EGFR-specific TMs were analyzed by SDS-PAGE (Figure 2BI) and immunoblotting (Figure 2BII). The results confirm that both constructs were successfully expressed as full-length proteins and can be detected via their $\mathrm{C}$-terminal $\mathrm{His}_{6}-$ tag. By comparing the molecular weight of $36 \mathrm{kDa}$ with the theoretically calculated size of $32 \mathrm{kDa}$ it becomes obvious that the bivalent TM exhibits a slightly aberrant mobility which may be caused by posttranslational modifications or insufficient cleavage of the $\mathrm{N}$-terminal signal peptide. As already seen by SDS-PAGE (Figure 2BI) and also confirmed by HPLC size exclusion chromatography (Figure 2C), the eluates mainly contain the respective TMs $(\alpha$-EGFR-EGFR TM: $72 \%$ purity, $\alpha$-EGFR TM: $69 \%$ purity) but also high molecular weight (HMW) proteins. Similar contaminations were already detected in preparations of other TMs after isolation from culture supernatants of $\mathrm{CHO}$ cells [23-25]. Moreover, the same HMW proteins are co-purified from cell culture supernatant of $\mathrm{CHO}$ wildtype (wt) cells lacking any expression vectors (Figure 2C, $\mathrm{CHO} \mathrm{wt}$ ). Therefore, these co-isolated HMW proteins represent most probably proteins from $\mathrm{CHO}$ cell culture supernatants.

\section{Binding analysis of the novel bivalent $\alpha$-EGFR- EGFR TM}

In a first step, we estimated EGFR surface expression levels of tumor cells by flow-cytometry on the surface of different tumor cell lines using a commercial anti-EGFR $\mathrm{mAb}$ and the fluorescence-based QIFIKIT $^{\circledR}$. Four cell lines were selected namely A431, MDA-MB435S, FaDu, and PC3-PSCA cells. PC3-PSCA cells represent $\mathrm{PC} 3$ cells that were previously manipulated to overexpress the prostate stem cell antigen (PSCA) [24]. As summarized in Figure 3, A431 cells exhibit the highest $\left(1.6 \times 10^{6} \mathrm{EGFR} /\right.$ cell $)$ and MDA-MB-435S cells the lowest number of EGFR molecules per cell $\left(2 \times 10^{3}\right.$ EGFR/cell). FaDu cells show an intermediate $\left(2.2 \times 10^{5}\right.$ EGFR/cell) and PC3-PSCA cells a low EGFR surface expression $\left(1.8 \times 10^{4} \mathrm{EGFR} /\right.$ cell $)$.

Binding of both the monovalent $\alpha$-EGFR TM and the bivalent $\alpha$-EGFR-EGFR TM to these EGFR $^{+}$cell lines was compared by flow cytometry analysis (Figure 4). Binding was detected via the $\mathrm{mAb}$ directed against the UniCAR epitope. As shown in Figure 4, the bivalent $\alpha$-EGFR-EGFR TM is able to bind to all tested tumor cell

\section{UniCAR system (monovalent)}

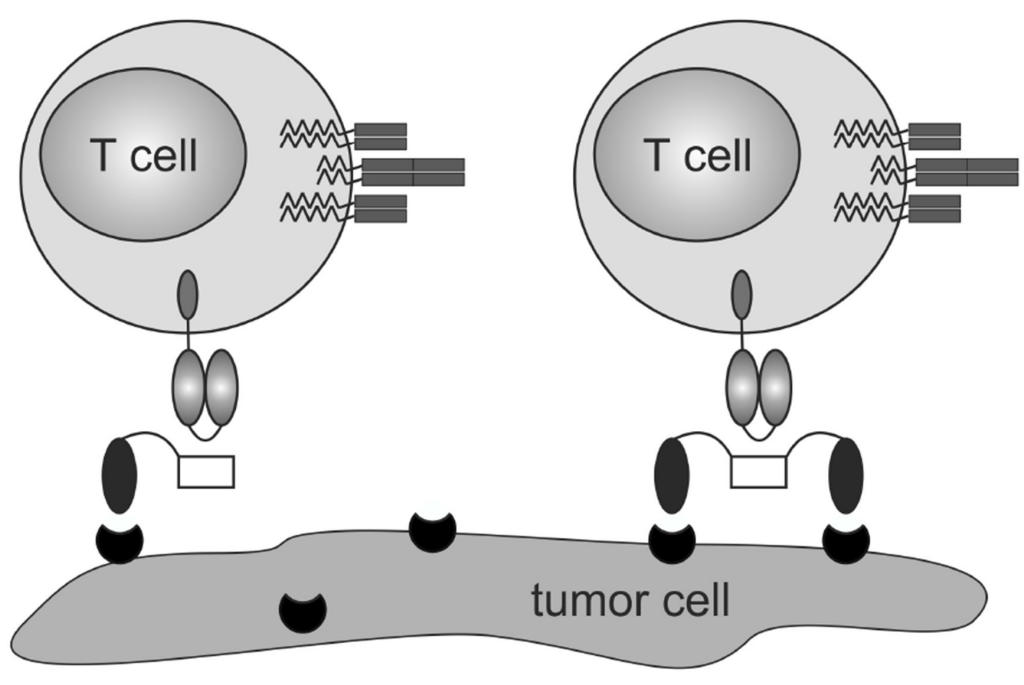

UniCAR system (bivalent)
Figure 1: Redirection of UniCAR-armed T cells via EGFR-specific target modules. The UniCAR system is based on two distinct components, the universal, signal-transducing UniCAR and a replaceable, tumor-specific target module (TM). By simultaneous binding of the tumor-associated antigen (here EGFR) and the $\alpha$-E5B9 single-chain fragment variable of the UniCAR, E5B9-tagged TMs are able to mediate a cross-linkage of T cells and tumor cells. For an EGFR-specific targeting, the TMs consist of either one (left panel, monovalent) or two nanobody domains (right panel, bivalent) with specificity for EGFR. 
A $\alpha$-EGFR-EGFR TM

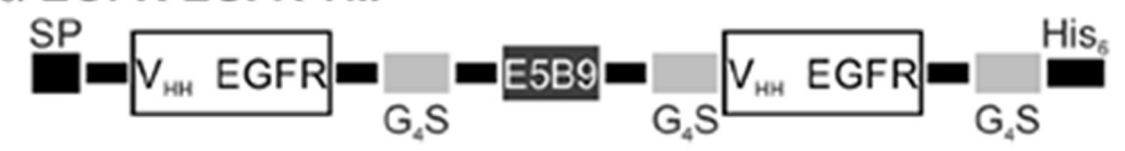

$\alpha$-EGFR TM
SP
$\mathrm{V}_{\mathrm{HH}}$ EGFR

BI

BII
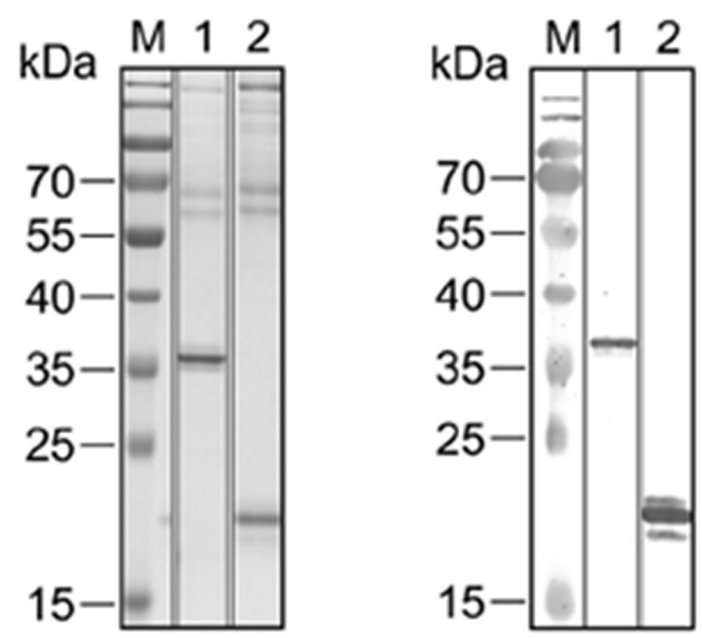

$M$ protein ladder

$1 \alpha$-EGFR-EGFR TM

$2 \alpha$-EGFR TM

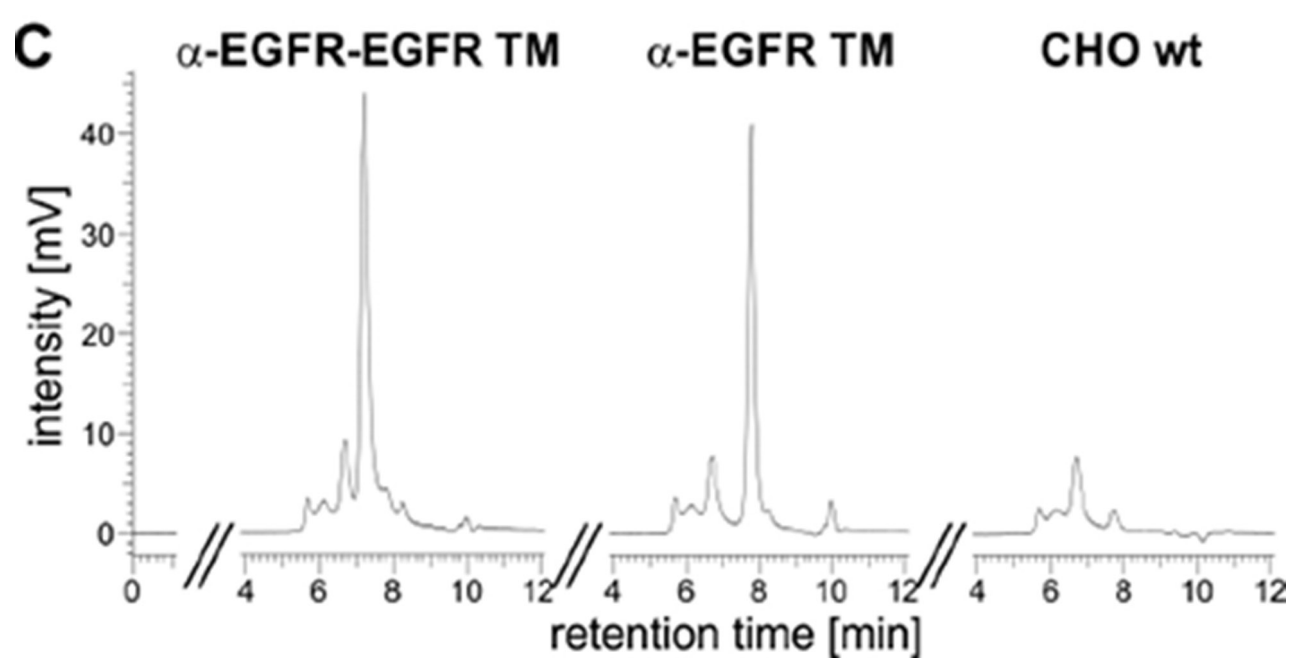

Figure 2: Biochemical characterization of the mono- and bivalent EGFR-specific TM. (A) The $\alpha$-EGFR-EGFR TM consists of two camelid Ab-derived $\alpha$-EGFR(7C12) nanobody domains $\left(\mathrm{V}_{\mathrm{HH}}\right)$ separated via the E5B9-tag while the monovalent $\alpha$-EGFR TM contains a single nanobody domain. The recombinant Abs are further equipped C-terminally with six histidine residues (His) for protein purification and detection. To ensure Ab secretion, the constructs are additionally endowed N-terminally with a signal peptide (SP). (B) After eukaryotic expression in CHO cells, the EGFR-specific TMs were purified by Ni-NTA affinity chromatography. The elution fractions of the $\alpha$-EGFR-EGFR TM (lane 1) and $\alpha$-EGFR TM (lane 2) were separated via SDS-PAGE and (BI) subsequently stained with Coomassie Brilliant Blue G250 or (BII) transferred onto nitrocellulose membranes to detect recombinant proteins via their C-terminal His $_{6}$-tag. M, molecular weight marker. (C) To further analyze the mono- and bivalent TM, $15 \mu \mathrm{g}$ of the respective elution fraction and 15 $\mu \mathrm{l}$ of purified $\mathrm{CHO}$ wt supernatant were analyzed by size exclusion chromatography. 
lines although the percentage of bound target cells varies in dependence on the EGFR expression level. In contrast, tumor cell binding of the monovalent $\alpha$-EGFR TM could only be verified for cell lines with high or intermediate EGFR expression namely A431 cells and FaDu cells.

These data also show that the UniCAR epitope present in both the mono- and bivalent TM is accessible for interactions with an Ab domain directed against this epitope even after binding of the respective TM to EGFR. This is an important prerequisite for the interaction of surface-bound TMs with UniCAR-equipped T cells.

Finally, we determined the $\mathrm{K}_{\mathrm{d}}$ values for binding of both the $\alpha$-EGFR-EGFR TM and the $\alpha$-EGFR TM to A431 or FaDu cells (Figure 5). In case of A431 cells, we estimated a $\mathrm{K}_{\mathrm{d}}$ value of $24 \mathrm{nM}$ for the $\alpha$-EGFR-EGFR TM and a $\mathrm{K}_{\mathrm{d}}$ value of $77 \mathrm{nM}$ for the $\alpha$-EGFR TM (Figure 5A). The superiority of the bivalent construct could be further confirmed by using FaDu cells (Figure 5B). With a $\mathrm{K}_{\mathrm{d}}$ value of $62 \mathrm{nM}$ the avidity of the bivalent TM increased 34 -fold in comparison to the monovalent $\alpha$-EGFR TM showing a $\mathrm{K}_{\mathrm{d}}$ value of $2084 \mathrm{nM}$.

\section{Effect of the novel bivalent $\alpha$-EGFR-EGFR TM on EGFR signaling}

Next, we analyzed whether or not the binding of the EGFR-specific TMs has an influence on EGFR signaling.
For this purpose, phosphorylation status of tyrosine 1068 of the EGFR was investigated. This phosphorylation site is the starting point of the Ras signaling pathway and docking site for Grb2 [37]. To look for potential agonistic effects of both the $\alpha$-EGFR-EGFR TM or the $\alpha$-EGFR TM, A431 tumor cells were incubated for $15 \mathrm{~min}$ at $37^{\circ} \mathrm{C}$ in the absence or presence of EGF or the respective TM instead (Figure 6A). As expected EGF induced phosphorylation of EGFR. In contrast, no specific EGFR phosphorylation was detected upon binding of the TMs. According to these data, the Nbbased constructs have no intrinsic activity under the tested circumstances. Furthermore, we analyzed the ability to block EGF-induced phosphorylation. For this purpose, A431 cells were incubated with a mixture of EGF $(8 \mathrm{nM})$ and increasing amounts of the respective TM (1 nM to $1000 \mathrm{nM})$. As shown in Figure 6B, none of the tested concentrations of the monovalent $\alpha$-EGFR TM blocked EGF effects. In general, results obtained with the bivalent $\alpha$-EGFR-EGFR TM were similar though at the highest TM concentration a slight inhibition was detectable. However, such a high TM concentration would never be reached during treatment of a patient as shown below (see estimation of $\mathrm{EC}_{50}$ value (Figure 8) and discussion section). Hence, the TM binding to EGFR does neither cause nor interfere with EGF-mediated signaling at least under retargeting conditions.

A
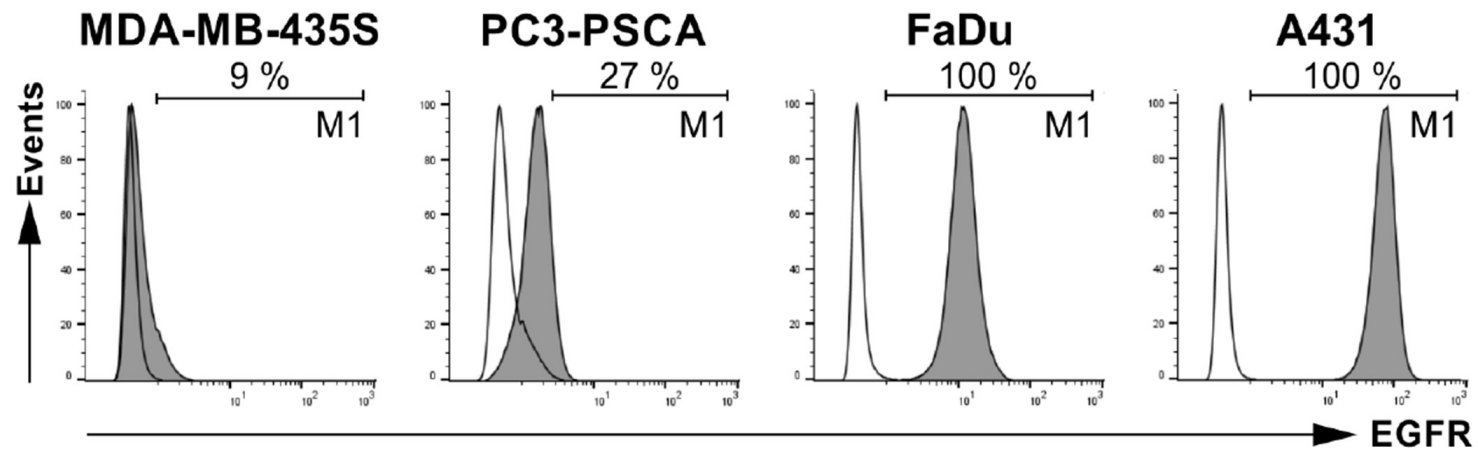

B

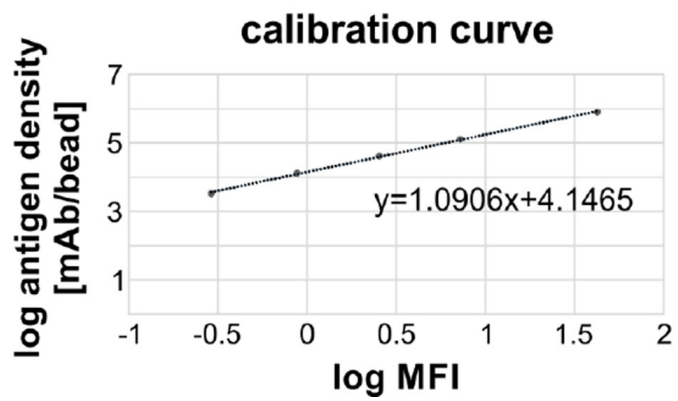

C

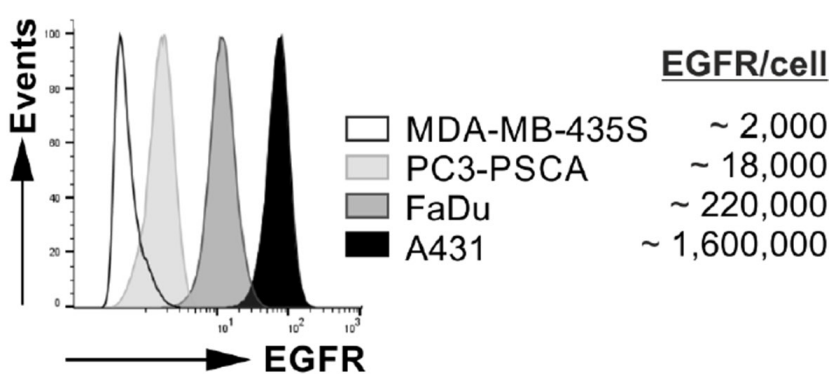

Figure 3: EGFR expression on different human tumor cell lines. Analysis of cell surface EGFR expression level was performed by flow cytometry using fluorescence-based QIFIKIT ${ }^{\circledR}$. For antigen detection an $\alpha$-EGFR IgG1 mAb and a FITC-conjugated $\alpha$-mouse IgG mAb were applied. (A) Histograms show staining of MDA-MB-435S, PC3-PSCA, FaDu or A431 cells (gray graphs) in comparison to the respective controls (transparent graphs). The corresponding percentage of EGFR-positive cells is displayed under the marker M1. (B) To calculate the EGFR antigen density a calibration curve was generated by using calibration beads. (C) Comparison of EGFR-binding on different tumor cell lines and the respective number of EGFR molecules per cell. 


\section{Redirection of UniCAR-armed $T$ cells via the novel bivalent TM enhances lysis of EGFR- expressing tumor cells}

In order to analyze whether the increased avidity of the $\alpha$-EGFR-EGFR TM influences its ability to redirect UniCAR-engrafted $\mathrm{T}$ cells for an efficient killing of different $\mathrm{EGFR}^{+}$cancer cells, chromium-based killing assays were performed. Therefore, human $\mathrm{T}$ cells were transduced with a lentiviral vector encoding the UniCAR $28 / \zeta$ signaling-construct. Genetically modified T cells expressing solely EGFP (vector control) or the UniCAR without intracellular signaling domains (UniCAR Stop) served as negative controls. Tumor cell lysis was determined by measuring chromium release after $48 \mathrm{~h}$ of co-cultivation (Figures 7 and 8). Analysis was carried out in comparison to the monovalent $\alpha$-EGFR TM.

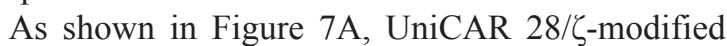
$\mathrm{T}$ cells are able to efficiently eradicate tumor cells in the presence of the $\alpha$-EGFR-EGFR TM. In line with the TMbinding data (Figure 4), tumor cell lysis correlates with the antigen density on the respective target cells. Highest lysis rate was observed for A431 cells, intermediate to low lysis rate for FaDu and PC3-PSCA cells, respectively, while MDA-MB-435S cells were not eliminated (Figure 7A). In contrast to the bivalent $\alpha$-EGFR-EGFR TM, the monovalent $\alpha$-EGFR TM is less efficient and mediates solely a significant eradication of cancer cells with high EGFR density (Figure 7B). No considerable tumor cell killing by UniCAR $28 / \zeta$-equipped T cells was measured in the absence of any TM. Additionally, UniCAR Stopand vector control-transduced T cells were not able to lyse target cells.
In a next step, ${ }^{51} \mathrm{Cr}$-labeled $\mathrm{A} 431$ tumor cells and UniCAR $28 / \zeta$-armed $\mathrm{T}$ cells were incubated with different concentrations of the TMs ranging between 0 and $50 \mathrm{nM}$ (Figure 8). The obtained data clearly underline that the bivalent $\alpha$-EGFR-EGFR TM is superior to the monovalent $\alpha$-EGFR TM regarding functionality. UniCAR T cellmediated lysis of A431 cells already reached a maximum efficiency at concentrations of $0.05 \mathrm{nM}$ for the bivalent $\alpha$-EGFR-EGFR TM, while 100-fold higher concentrations of the monovalent $\alpha$-EGFR TM were required. This is in line with the $\mathrm{EC}_{50}$ value calculated for the bivalent $\alpha$-EGFR-EGFR TM that is 250 times lower $(0.007 \mathrm{nM})$ than that of the monovalent $\alpha$-EGFR TM $(1.8 \mathrm{nM})$. As also seen for previously described TMs, tumor cell lysis varied in a wide range between the different $\mathrm{T}$ cell donors.

\section{Cytokine release of cross-linked UniCAR-armed T cells}

Based on previous studies, including for the monovalent $\alpha$-EGFR TM using a multiplex assay (the MACSPlex Cytokine $12 \mathrm{Kit}$ ) we know that the major cytokines released from UniCAR-armed T cells are GMCSF, IFN- $\gamma$, IL-2, and TNF. Other cytokines including IL-4, IL-5, IL-6, IL-9, IL-10, IL-12, IL-17A could not be detected at a significant concentration [23-25]. Therefore, in this study we focused on the cytokines IFN- $\gamma$, TNF and IL-2. To estimate secreted concentrations, UniCAR 28/ל-equipped T cells were co-cultivated with A431 tumor cells (expressing high levels of EGFR) in the absence or presence of either the mono- or bivalent EGFR-specific TM. Additionally, effector T cells were incubated solely with the TMs in the absence of A431 cells to exclude
MDA-MB-435S

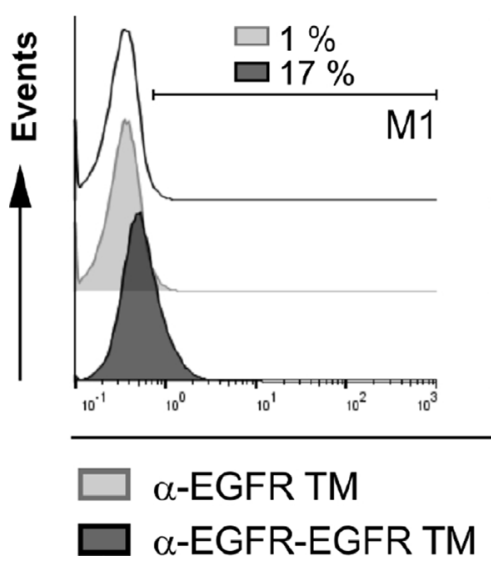

PC3-PSCA

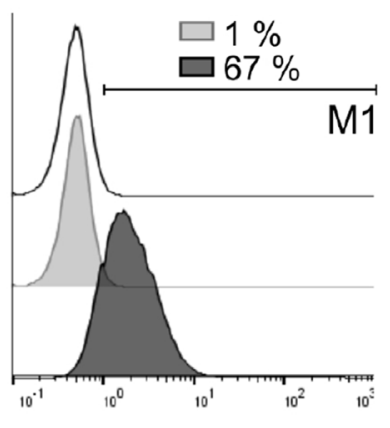

FaDu

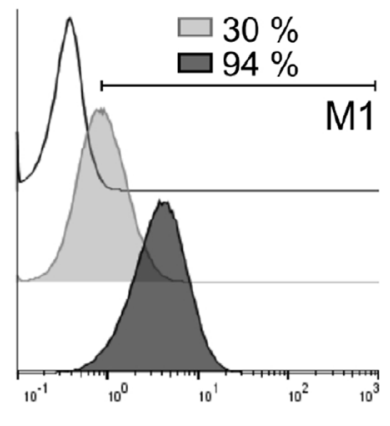

A431

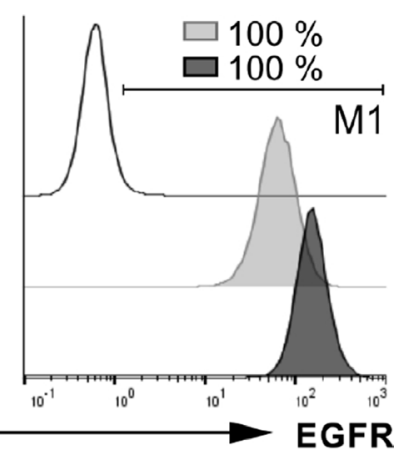

Figure 4: Binding of EGFR-specific TMs to antigen-expressing tumor cells. To compare binding properties of the bivalent $\alpha$-EGFR-EGFR TM with the monovalent $\alpha$-EGFR TM, MDA-MB-435S, PC3-PSCA, FaDu and A431 cells were stained with $20 \mathrm{ng} / \mathrm{ml}$ of the respective construct. Specific binding was detected with an $\alpha$-E5B9 mAb and a Pacific Blue ${ }^{\mathrm{TM}}$-conjugated $\alpha-\mathrm{mouse}-\mathrm{IgG}$ (Fc $\gamma$ ) $\mathrm{mAb}$. Histograms show different tumor cell lines stained with the bivalent TM (dark gray graphs) or the monovalent TM (light gray graphs) in comparison to the respective controls (transparent graphs). In order to estimate the percentage of cells positively stained with the TMs, the marker M1 was set relative to the corresponding negative control. Respective numbers are given in each histogram. One representative experiment of three is shown. 
unspecific TM effects. After $48 \mathrm{~h}$ of cultivation, cell culture supernatants were analyzed by ELISA for release of IFN- $\gamma$, TNF and IL-2 (Figure 9). In general, cytokines were only detected after incubation of UniCAR $28 / \zeta$-armed $\mathrm{T}$ cells and tumor cells in the presence of

TMs. Thus, cytokine release is strictly dependent on the
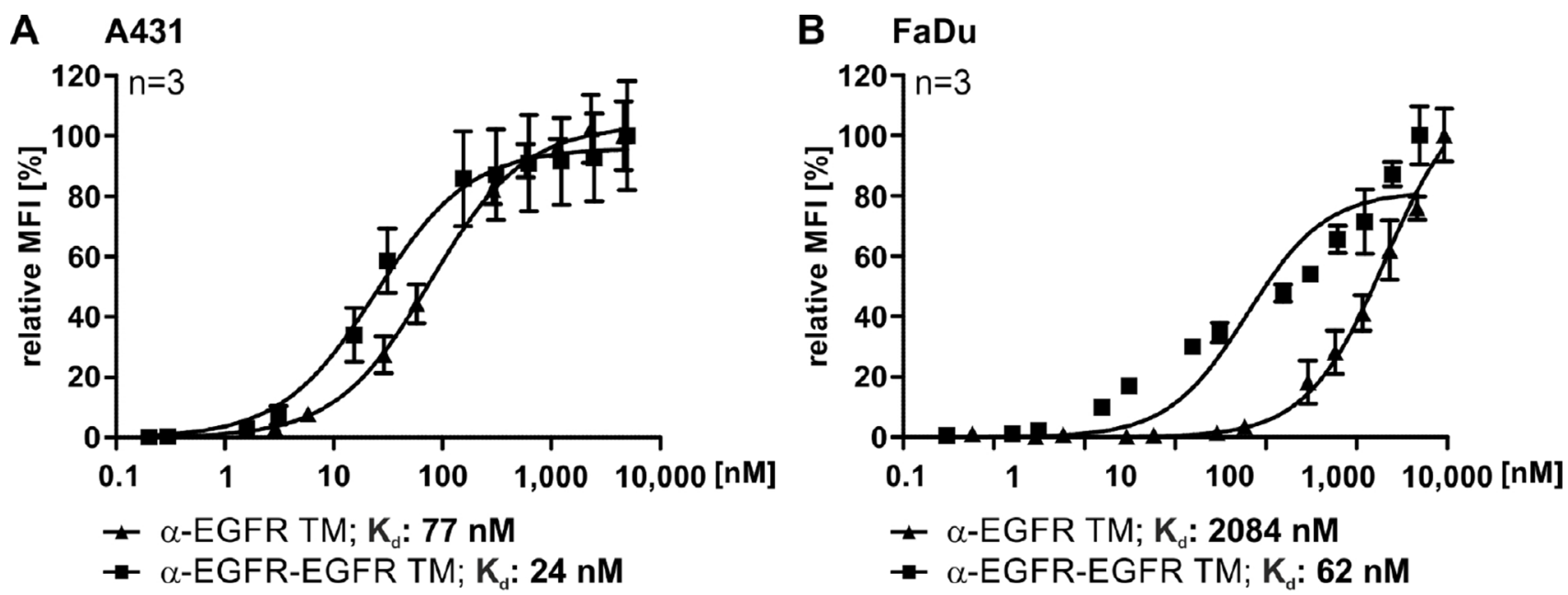

Figure 5: Comparison of the affinities of the mono- and bivalent EGFR-specific TMs. For estimation of the respective $\mathrm{K}_{\mathrm{d}}$ value increasing amounts of monovalent $\alpha$-EGFR TM (triangle) or bivalent $\alpha$-EGFR-EGFR TM (rectangle) were used to stain EGFRpositive (A) A431 or (B) FaDu cells. Detection of the specific binding was performed via the E5B9-tag with an $\alpha$-E5B9 mAb and a Pacific Blue $^{\mathrm{TM}}$-conjugated $\alpha$-mouse-IgG $(\mathrm{Fc} \gamma) \mathrm{mAb}$. The resulting binding curves were used to calculate the $\mathrm{K}_{\mathrm{d}}$ values. Average relative MFI and $\mathrm{SD}$ of three independent experiments are shown.
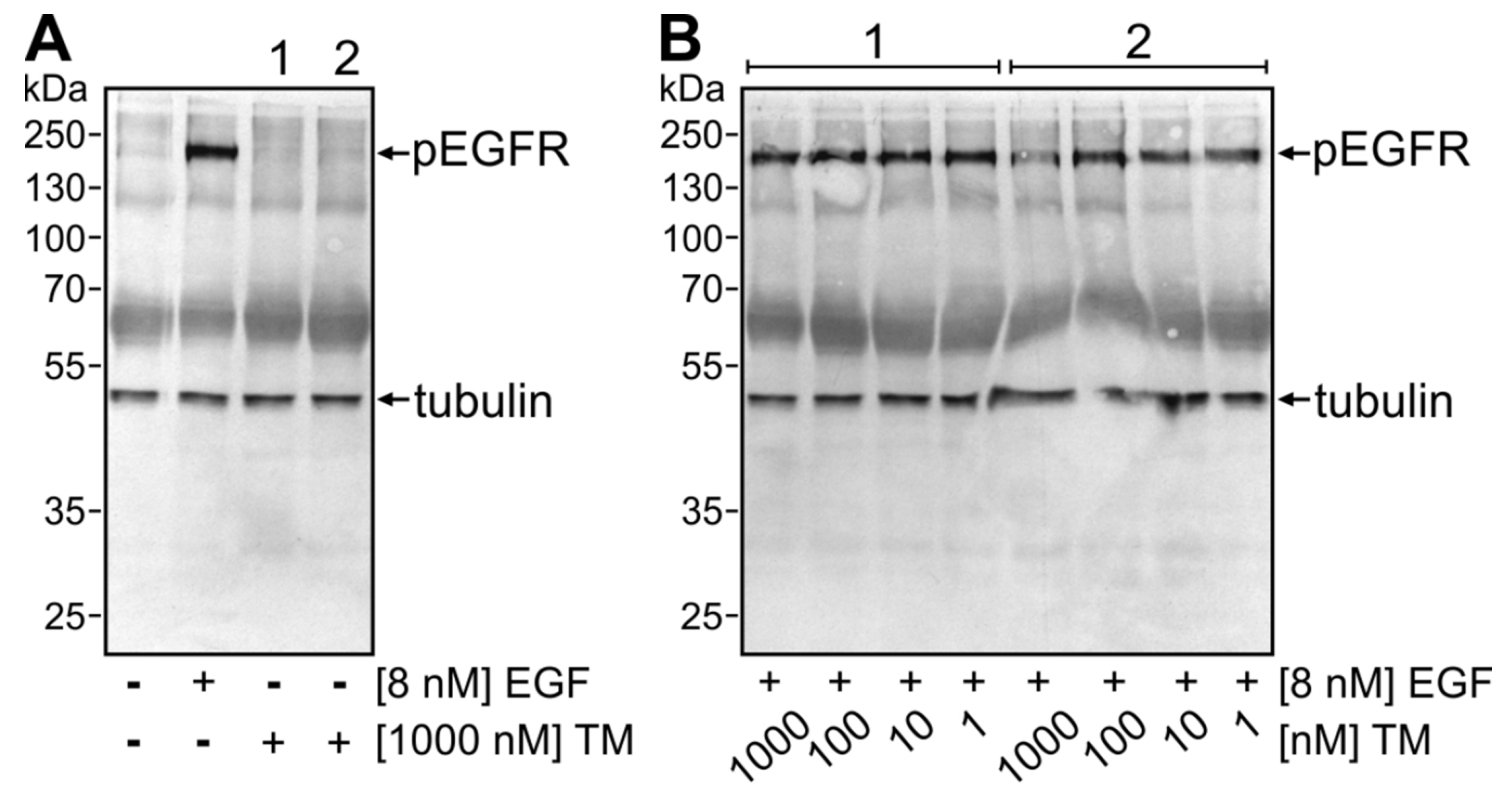

\section{$1 \alpha-E G F R$ TM \\ $2 \alpha$-EGFR-EGFR TM}

Figure 6: Influence of the mono- and bivalent EGFR-specific TMs on EGFR signaling. (A) Serum-starved A431 tumor cells were incubated at $37^{\circ} \mathrm{C}$ either with no ligand, $8 \mathrm{nM} \mathrm{EGF,} 1000 \mathrm{nM} \alpha$-EGFR TM (lane 1) or $1000 \mathrm{nM} \alpha$-EGFR-EGFR TM (lane 2). After $15 \mathrm{~min}$, cells were harvested and total cell lysates were separated by SDS-PAGE and subsequently transferred onto a nitrocellulose membrane. Afterwards, membranes were stained with mAbs against phosphorylated EGFR (pEGFR) and $\beta$-tubulin as loading control. (B) Mixtures of EGF $(8 \mathrm{nM})$ and increasing amounts of the respective TM between $1 \mathrm{nM}$ and $1000 \mathrm{nM}$ were added to serum-starved A431 cells. Immunochemical detection of pEGFR was performed as described in (A). 


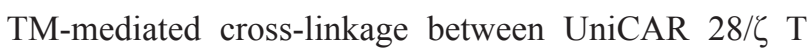
cells and tumor cells. The bivalent TM triggers a higher release of pro-inflammatory cytokines IFN- $\gamma$ and TNF as well as growth-promoting cytokine IL-2 in comparison to the monovalent TM. Besides, IFN- $\gamma$ represented the most prominent cytokine secreted by EGFR-redirected UniCAR-armed T cells.

\section{Superior in vivo anti-tumor reactivity of the bivalent TM}

By using an established xenograft mouse tumor model, the functionality of the monovalent $\alpha$-EGFR TM and the bivalent $\alpha$-EGFR-EGFR TM was finally compared in vivo. As described recently, A431 cells genetically modified to express firefly luciferase (termed A431-Luc) served as target cells [23]. Under the chosen experimental conditions, UniCAR-modified $\mathrm{T}$ cells armed with the monovalent $\alpha$-EGFR TM were able to completely eliminate the injected tumor cells [23]. In order to challenge the question whether or not the improved in vitro killing efficacy of the bivalent $\alpha$-EGFR-EGFR TM turns also into an improved antitumor functionality in vivo, we reduced the amount of TMs ten times (down to $600 \mathrm{pmol}$ per mouse) compared to the previously described experiment. Under these circumstances, we expected to see little if any effect by administering the monovalent $\alpha$-EGFR TM, while the bivalent $\alpha$-EGFR-EGFR TM should still be functional. For this experiment, $1.5 \times 10^{6} \mathrm{~A} 431$-Luc cells were mixed with UniCAR $28 / \zeta$-armed T cells at an effector-to-target cell ratio of $1: 1$ and the respective TM. A431-Luc cells alone or mixed with UniCAR $28 / \zeta \mathrm{T}$ cells without any TM served as negative controls. The respective mixtures
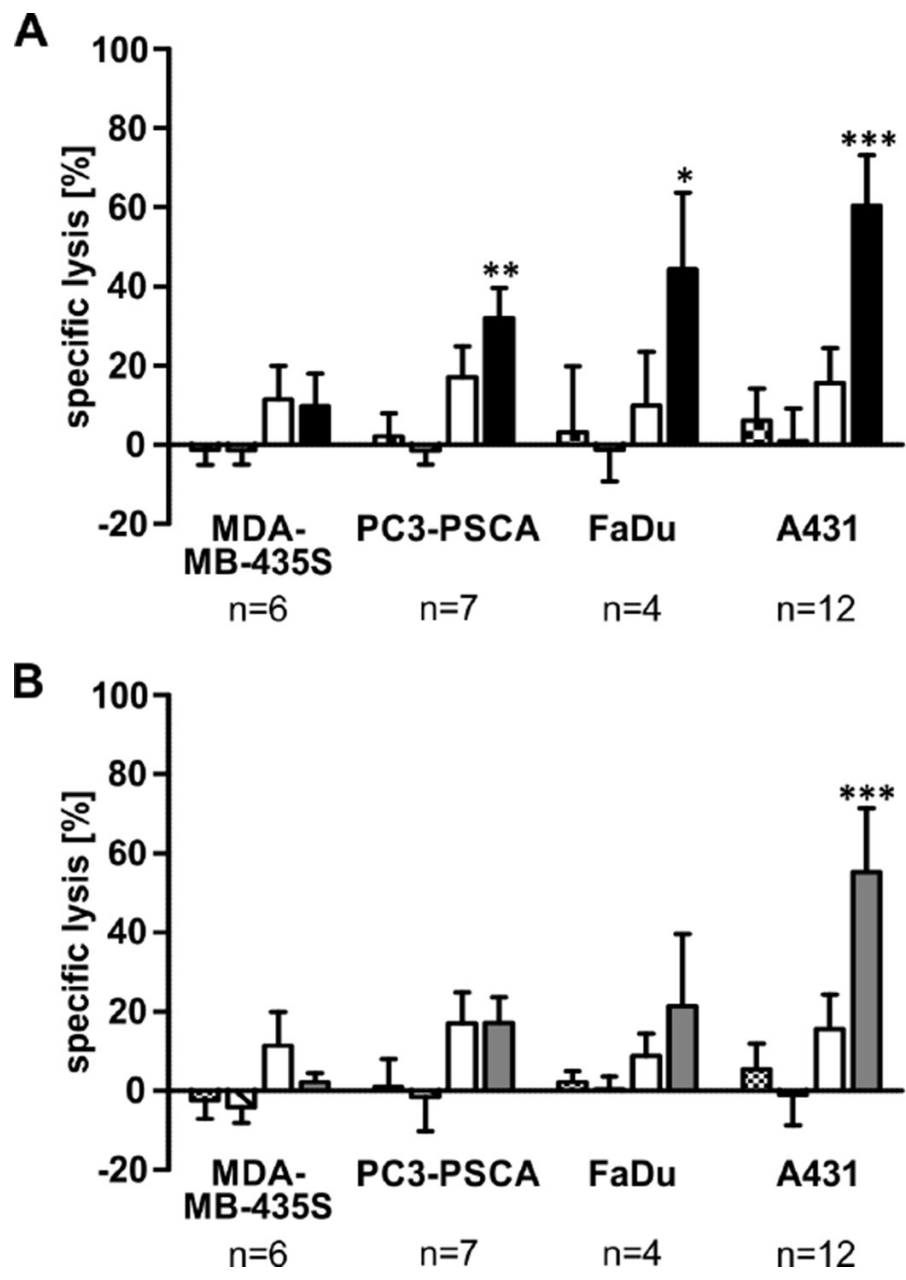

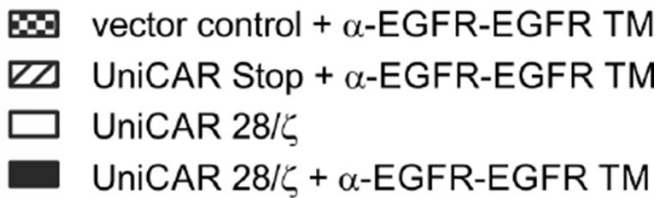

Figure 7: Retargeting of UniCAR-armed T cells against EGFR-positive tumor cell lines via EGFR-specific TMs. Killing properties were analyzed by standard chromium release assays. Therefore, $T$ cells engrafted with the EGFP-expressing vector

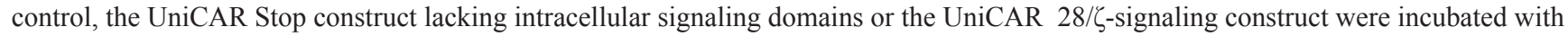
${ }^{51} \mathrm{Cr}$-loaded MDA-MB-435S, PC3-PSCA, FaDu or A431 cells. The co-cultivation of T cells and tumor cells was performed at an effector to target cell ratio of 5:1 in the presence or absence of $50 \mathrm{nM}$ (A) $\alpha$-EGFR-EGFR TM or (B) $\alpha$-EGFR TM for 48 h. Average specific lysis and SD for six (MDA-MB-435S), seven (PC3-PSCA), four (FaDu) or twelve (A431) independent $\mathrm{T}$ cell donors are shown $\left({ }^{*} p<0.05\right.$,

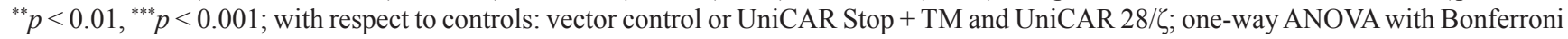
multiple-comparison test). 
were subcutaneously injected into female $\mathrm{NMRI}^{\mathrm{nu} / \mathrm{nu}}$ mice resulting in four groups of animals (Figure 10). By performing bioluminescence imaging, the tumor growth of luciferase-expressing cells was monitored. All mice were analyzed in parallel at day 0 (Figure 10, D0), day 2 (Figure 10, D2) and day 7 (Figure 10, D7). As shown in Figure 10, A431 Luc cells were visible in all experimental mice including the treatment groups directly after s.c. injection of the respective TM/cell mixtures. Seven days later, tumor cells could no longer be detected in the treatment group receiving the bivalent $\alpha$-EGFR-EGFR $\mathrm{TM}$. In contrast, luciferase activity was still visible in both control animals and experimental mice treated with the monovalent $\alpha$-EGFR TM. These data indicate that under the applied experimental conditions only the bivalent $\alpha$-EGFR-EGFR TM was able to successfully redirect UniCAR-armed $\mathrm{T}$ cells against EGFR-positive tumor cells in vivo thus underlining the superiority of the bivalent $\alpha$-EGFR-EGFR TM.

\section{Biodistribution of the bivalent $\alpha$-EGFR-EGFR TM in tumor bearing mice}

For analysis of the biodistribution and estimation of the pharmacokinetic behavior of the TM both the monovalent $\alpha$-EGFR TM and the bivalent $\alpha$-EGFREGFR TM were radiolabeled. Prior to radiolabeling, we had to remove the contaminating HMWs [25]. The resulting purity of purified $\alpha$-EGFR-EGFR TM was better than $95 \%$ as estimated by SDS-PAGE (Supplementary Figure 1A) and HPLC (data not shown). Purified TMs were conjugated with the chelator NODAGA [23, 25] (see Materials and Methods). After conjugation the modified $\alpha$-EGFR-EGFR-NODAGA TM was functionally compared with the unmodified $\alpha$-EGFR-EGFR TM. As shown in Supplementary Figure 1B, the conjugation of NODAGA did not impair the functionality of the $\alpha$-EGFREGFR TM. NODAGA can be used for chelating of ${ }^{64} \mathrm{Cu}$. The resulting radiolabeled bivalent $\left[{ }^{64} \mathrm{Cu}\right] \mathrm{Cu}-\alpha$-EGFREGFR-NODAGA TM and monovalent $\left[{ }^{64} \mathrm{Cu}\right] \mathrm{Cu}-\alpha$-EGFRNODAGA TM had a molar activity larger than $24 \mathrm{GBq} /$ $\mu \mathrm{mol}$ and was of high radiochemical purity ( $>95 \%$ ).

The biodistribution of the $\left[{ }^{64} \mathrm{Cu}\right] \mathrm{Cu}-\alpha$-EGFR-EGFRNODAGA TM is summarized in Figure 11. Diagrams show activity amounts in the whole organs either as percentage of the total activity of the injected dose (\%ID) (Figure 11A) or the activity concentration (SUV) for a total of four A431-Luc tumor bearing mice (Figure 11B) $2 \mathrm{~h}$ after injection. Target to background ratios including tumor-to-muscle-, and tumor-to-blood ratios are shown in Figure 11C. Data reveal that the bivalent TM is eliminated via glomerular filtration into the urine as well as via the hepatobiliary system. This is in contrast to the monovalent TM, which is mainly eliminated via the kidneys [23].

As shown by small animal PET/CT the $\left[{ }^{64} \mathrm{Cu}\right] \mathrm{Cu}-$ $\alpha$-EGFR-EGFR-NODAGA TM enriched at the tumor
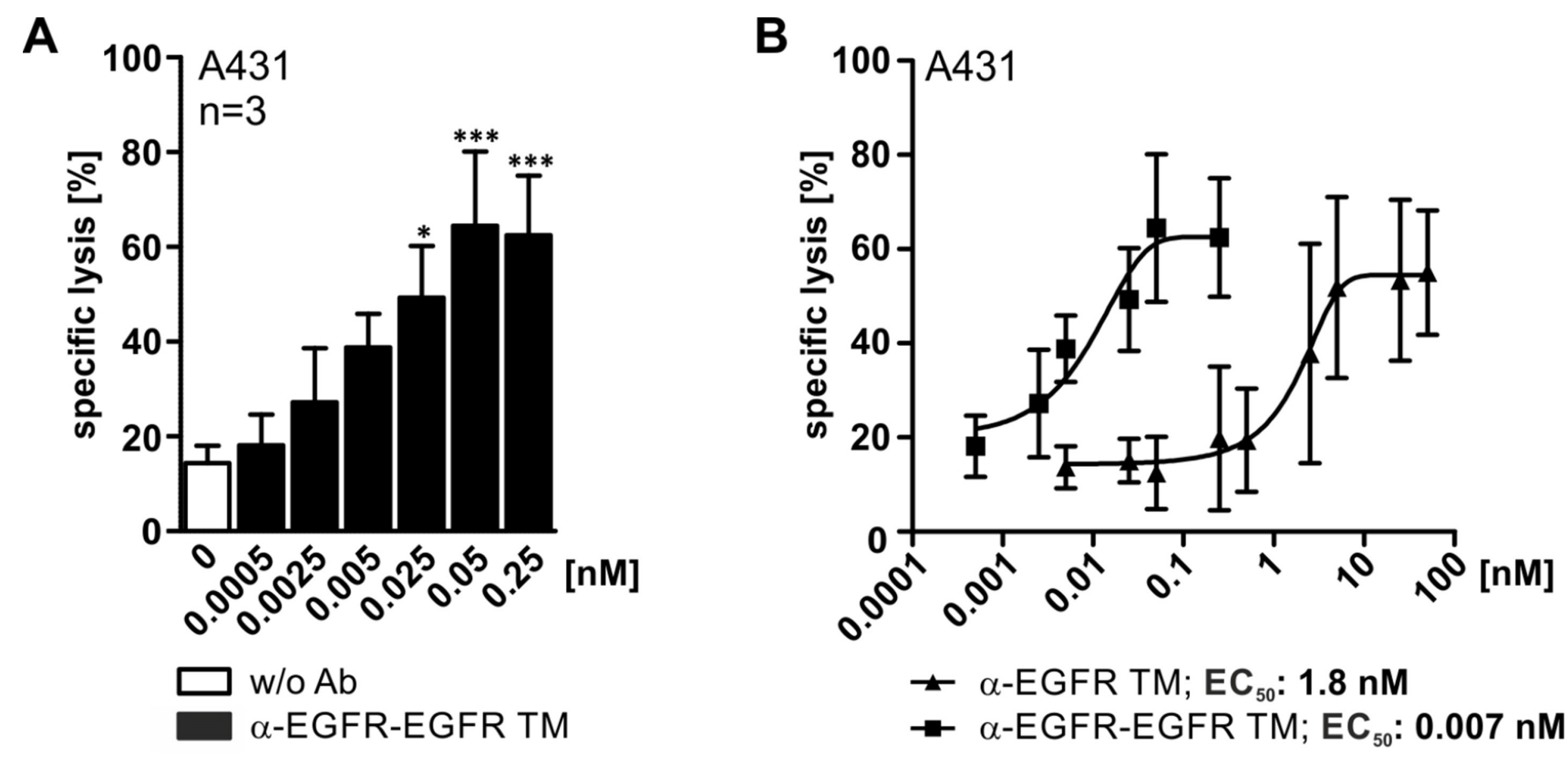

Figure 8: Comparison of working concentrations for the mono- and bivalent EGFR-specific TMs. To estimate the TM-

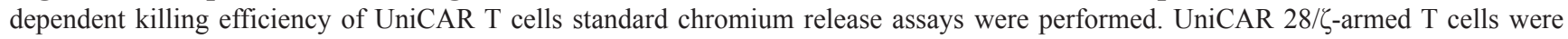
cultivated with ${ }^{51} \mathrm{Cr}$-labeled A431 cells in an effector to target cell ratio of 5:1 with increasing amounts of EGFR-specific TM for 48 h. (A) Shown data represent mean specific lysis and SD for three independent T cell donors incubated with the bivalent $\alpha$-EGFR-EGFR TM $\left({ }^{*} p<\right.$

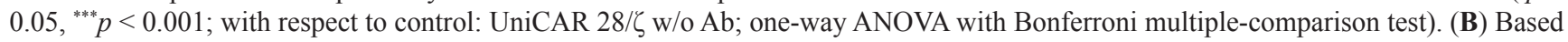
on the specific lysis of chromium release assays the $\mathrm{EC}_{50}$ values were calculated. The graph displays the comparison of the calculated killing curves for the monovalent and the bivalent EGFR-specific TM. Mean specific lysis and SD for five (monovalent TM) or three (bivalent TM) independent T cell donors are shown. 
site already after 2 h (Figure 12, upper panel). However, the maximal tumor activity concentration and maximal contrast was not reached at this time point. A portion of the tracer $\left[{ }^{64} \mathrm{Cu}\right] \mathrm{Cu}-\alpha$-EGFR-EGFR-NODAGA TM can still easily be detected in the blood and heart of the analyzed mouse, which is consistent with the high blood activity concentration measured in the biodistribution (Figure 11). Thus, the tracer can further enrich at the tumor site during the following $18 \mathrm{~h}$ (Figure 12, lower panel).

In order to support this pharmacokinetic behavior of the bivalent tracer $\left[{ }^{64} \mathrm{Cu}\right] \mathrm{Cu}-\alpha$-EGFR-EGFR-NODAGA TM, time-activity curves (TAC) of regions of interest (ROI) derived from dynamic PET studies of four analyzed A431-Luc tumor bearing mice were estimated. The midframe data points were calculated over a time range of $2 \mathrm{~h}$ p.i. of the $\left[{ }^{64} \mathrm{Cu}\right] \mathrm{Cu}-\alpha$-EGFR-EGFR-NODAGA TM (Figure 13). TAC representing primarily the tumor, blood, and muscle activity concentration estimated as $\mathrm{SUV}_{\text {mean }}$ are shown in Figure 13A. The respective curve of the blood indicates a rapid elimination of the bivalent TM with a serum half-life of only $9.3 \mathrm{~min}$. Additionally, the TAC of the tumor shows that the TM has a clearance half-life of $5.2 \mathrm{~h}$. TACs of the tumor-to-blood and tumorto-muscle ratios, are presented in Figure 13B and Figure $13 \mathrm{C}$, respectively. In agreement with the data presented in Figure 12, these results support the interpretation that the maximal image contrast is not reached $2 \mathrm{~h}$ p.i.. Altogether these data indicate that the pharmacokinetic behavior of the bivalent $\left[{ }^{64} \mathrm{Cu}\right] \mathrm{Cu}-\alpha$-EGFR-EGFR-NODAGA TM differs from the previously described [23] monovalent $\left[{ }^{64} \mathrm{Cu}\right] \mathrm{Cu}-\alpha$-EGFR-NODAGA TM as also supported by the side by side comparison of both radiolabeled TMs (Figure 14A). As mentioned above (and also seen in Figure 14A, left panel), $2 \mathrm{~h}$ p.i. the bivalent $\left[{ }^{64} \mathrm{Cu}\right] \mathrm{Cu}-\alpha$-EGFR-EGFRNODAGA TM is still detectable in the heart/blood stream of the experimental mouse. In contrast, the monovalent $\alpha$-EGFR tracer is almost completely eliminated from the heart/blood stream at this time (Figure 14A, right panel). Therefore, the monovalent $\left[{ }^{64} \mathrm{Cu}\right] \mathrm{Cu}-\alpha$-EGFR-NODAGA TM cannot further enrich at the tumor site but already decreases between $1.5 \mathrm{~h}$ and $24 \mathrm{~h}$ p.i. (Figure 14B, blue bars). In contrast, the bivalent $\left[{ }^{64} \mathrm{Cu}\right] \mathrm{Cu}-\alpha$-EGFR-EGFRNODAGA TM has not reached its maximum concentration $1.5 \mathrm{~h}$ p.i. and can further enrich at the tumor site during the following $22.5 \mathrm{~h}$ (Figure 14B, red bars, see also Figure 12).

\section{DISCUSSION}

The key to success in development of novel promising immunotherapeutic approaches is based on two factors: (I) high effectiveness at (II) lowest possible side effects. Particularly CAR-armed T cells represent attractive candidates for highly effective cancer care. Although first CAR T cell therapies have finally entered the clinical routine for treatment of cancer patients $[38,39]$, there is still the need to further improve the safety of such "living drugs". Most concerning side effects associated with CAR T cell therapy are CRS and

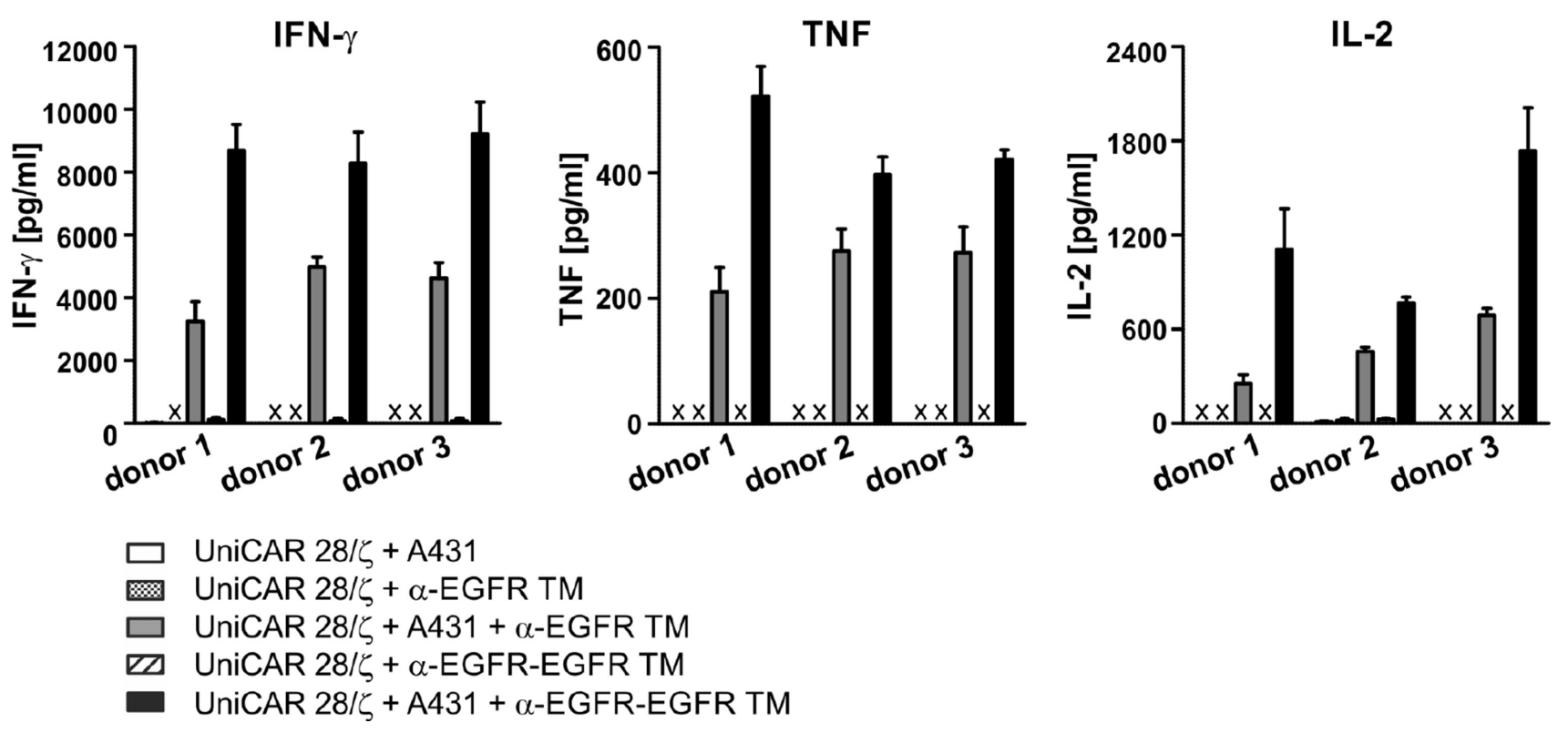

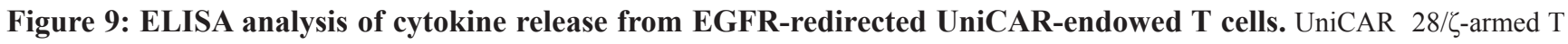
cells were cultivated with A431 tumor cells in the presence or absence of $50 \mathrm{nM} \alpha$-EGFR TM or $\alpha$-EGFR-EGFR TM at an effector to target

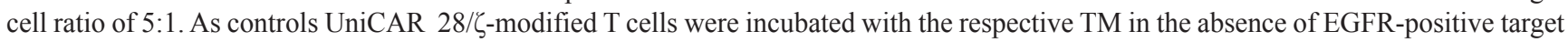
cells. After $48 \mathrm{~h}$, concentrations of the cytokines IFN- $\gamma$, TNF and IL-2 were estimated in cell culture supernatants by ELISA. The average cytokine concentration and SD from experiments for three independent donors are shown (x, not detectable). 
uncontrollable "on-target, off-tumor" reactions against healthy tissues with low TAA expression [35]. As shown by a case report using Her2/neu-specific CAR T cells, these adverse reactions can even be fatal [40]. Considering the ubiquitous expression of the HER family members, targeting of EGFR requires a sophisticated safety management and has to go beyond the currently available pharmacological immunosuppression [35]. Keeping the long-term persistence of CAR-engrafted T cells in mind $[41,42]$, EGFR-targeted therapy requires the shutdown of adoptively transferred immune effector cells to avoid permanent destruction of healthy tissues. Thus, we came up with the idea to manage the safety issue by separating the functional domains of CAR constructs and developed a novel platform technology termed UniCAR [22-27]. This modular tumor targeting strategy is based on T cells which are genetically modified to express the UniCAR and are per se inactive. Their anti-tumor reactivity can only be switched on and off in dependence of tumor-specific TMs recognized by the UniCAR. Hence, tumor killing mediated by UniCAR-modified T cells occurs in a TM dose-dependent manner allowing an easy reactivation at any time via renewed TM supply, e.g. in case of tumor relapse. Through titration of the TM unwanted treatmentrelated toxicities, including CRS and toxic effects against healthy tissues, can be easily managed.

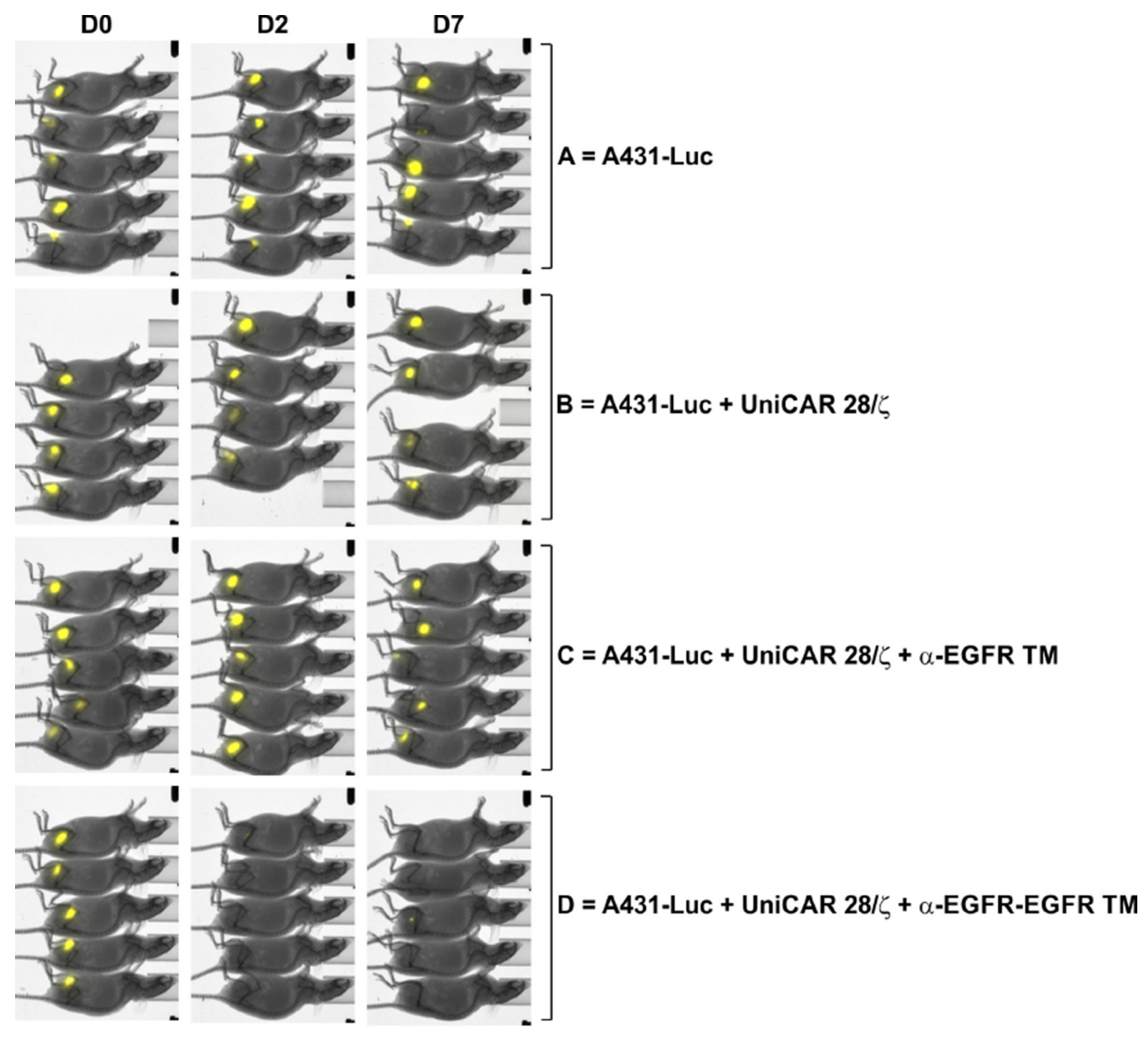

Figure 10: UniCAR system-based retargeting of EGFR-positive tumor cells in experimental mice. Comparison of monovalent versus bivalent TM. For each mouse of the treatment group mixtures of $1.5 \times 10^{6}$ A431-Luc cells, $1.5 \times 10^{6}$ UniCAR $28 / \zeta$-armed T cells and 600 pmol of the monovalent $\alpha$-EGFR TM (group C) or bivalent $\alpha$-EGFR-EGFR TM (group D) were prepared.

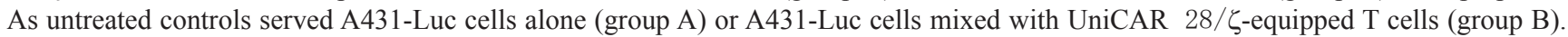
The respective mixtures were subcutaneously injected into the right flank of female NMRI ${ }^{\text {nunu }}$ mice resulting in four groups of animals. At day 0 (D0), day 2 (D2) and day 7 (D7) bioluminescence imaging of anesthetized mice was performed 10 min after i.p. injection of $200 \mu 1$ luciferin $(15 \mu \mathrm{g} / \mu \mathrm{l})$. 
So far, we have established a series of TMs for the UniCAR system including against CD33, CD123, CD19, PSCA, PSMA, and GD2 [22-27]. All these and other constructs (Bachmann, unpublished) were functional without any further optimization, although affinity of these TMs to the respective target cell varied in a wide range. Until now, we therefore assumed that the affinity between the UniCAR domain and its cognate epitope (E5B9) on the TM is most important for functionality, while the affinity between the surface TAA and the TM may be less relevant. We further expected that increasing the affinity towards the target site may even be counterproductive as the TM may stick to the surface of dead or apoptotic target cells and is therefore unavailable for binding to the next tumor cell.

However, this view was recently challenged when we analyzed the properties of a $\mathrm{Nb}$-based monovalent $\alpha$-EGFR TM that was expressed either in E. coli or in
CHO cells [23]. Both EGFR-specific TM preparations were proven to be suitable for cancer immunotherapy and PET-imaging of tumors. In experimental mice, the TMs were rapidly eliminated from the circulation and from UniCAR-TM complexes, thus fulfilling all requirements for safety management by TM dosing. Yet for an unknown reason, the $\alpha$-EGFR TM (pro) had a higher affinity and was more efficient than the $\alpha$-EGFR TM expressed by eukaryotic cells. It remained, however, unclear whether or not the improved functionality of the TM expressed in prokaryotic cells was due to its higher affinity towards the target antigen. Nonetheless, these data demonstrate that the efficacy of the $\alpha$-EGFR TM does not solely depend on its primary sequence and can be improved perhaps by changing the affinity towards the TAA.

To rule out effects caused by different expression systems and to obtain a TM with an enhanced affinity towards EGFR, we decided to construct a bivalent TM

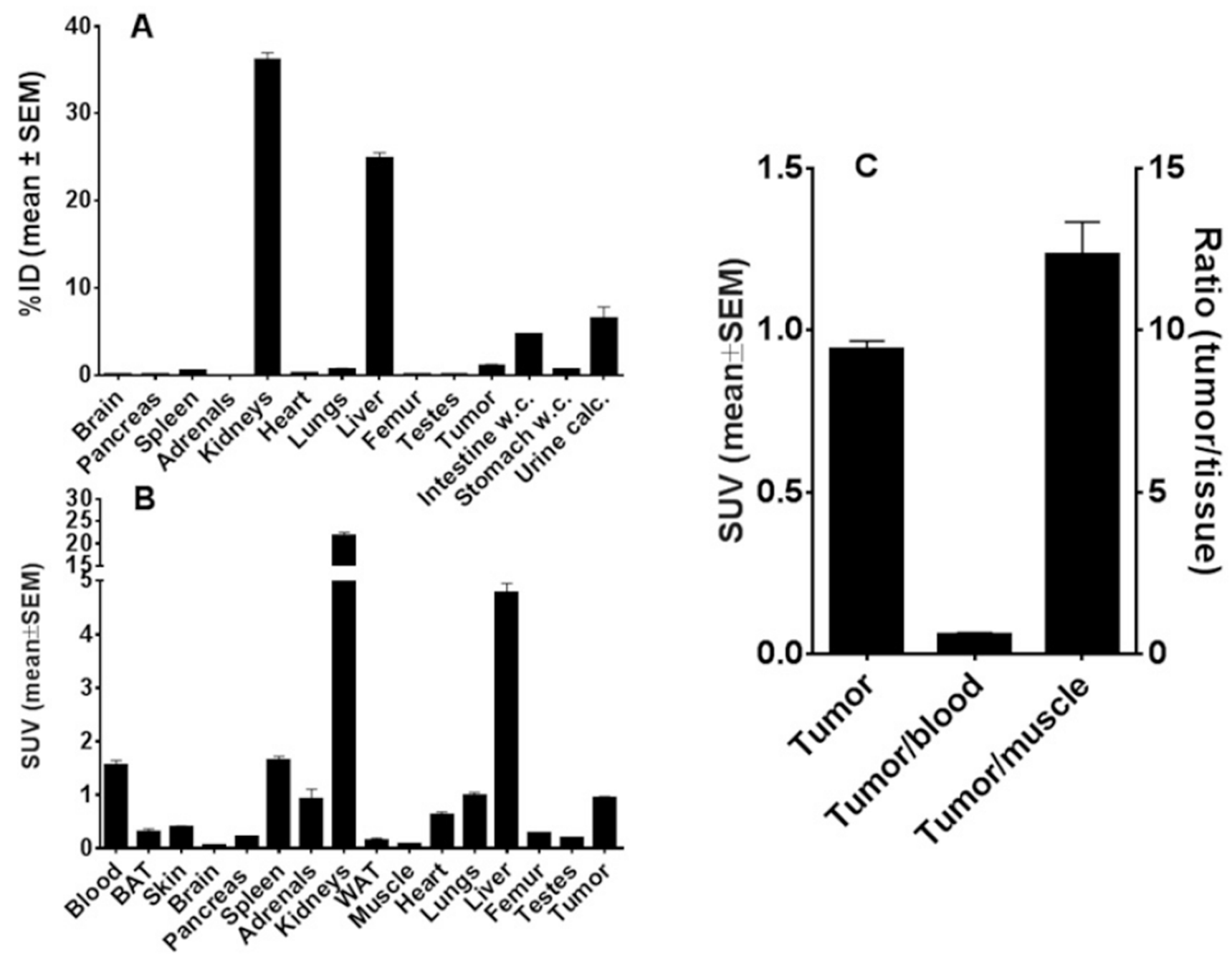

Figure 11: Biodistribution of ${ }^{64} \mathrm{Cu}$-radiolabeled $\boldsymbol{\alpha}$-EGFR-EGFR TM. After conjugation of the $\alpha$-EGFR-EGFR TM with NODAGA the resulting $\alpha$-EGFR-EGFR-NODAGA TM was radiolabeled with ${ }^{64} \mathrm{Cu}$. The biodistribution of the $\left[{ }^{64} \mathrm{Cu}\right] \mathrm{Cu}-\alpha$-EGFR-EGFRNODAGA TM complex is shown in (A, B). (A) The biodistribution is given as percentage of the total activity of the injected dose (\%ID) and (B) the activity concentration (SUV) based on four A431-Luc tumor bearing mice. (C) Target to background ratios including tumor-tomuscle-, and tumor-to-blood ratios. The data were collected $2 \mathrm{~h}$ after injection of the $\left[{ }^{64} \mathrm{Cu}\right] \mathrm{Cu}-\alpha$-EGFR-EGFR-NODAGA TM. 
and expressed it with the same eukaryotic CHO cell system like the monovalent $\alpha$-EGFR TM. Both EGFRspecific constructs are based on the camelid $\mathrm{Nb}$ clone 7C12. Since Roovers et al. reported (i) an inhibition of EGF-mediated EGFR phosphorylation in the presence of the EGFR-specific Nb 7D12 [43], and (ii) also mentioned a blockage of EGF binding by the $\mathrm{Nb} 7 \mathrm{C} 12$ used in our studies [43] we analyzed the capability of our $\alpha$-EGFR TMs to mediate EGFR signaling and blocking of EGF binding to EGFR. Unfortunately, the data mentioned for the $\mathrm{Nb} 7 \mathrm{C} 12$ were not shown in detail making a direct comparison with our data difficult. Nonetheless, at least under our retargeting conditions we do not see either an intrinsic receptor activation or blockage of EGF-mediated

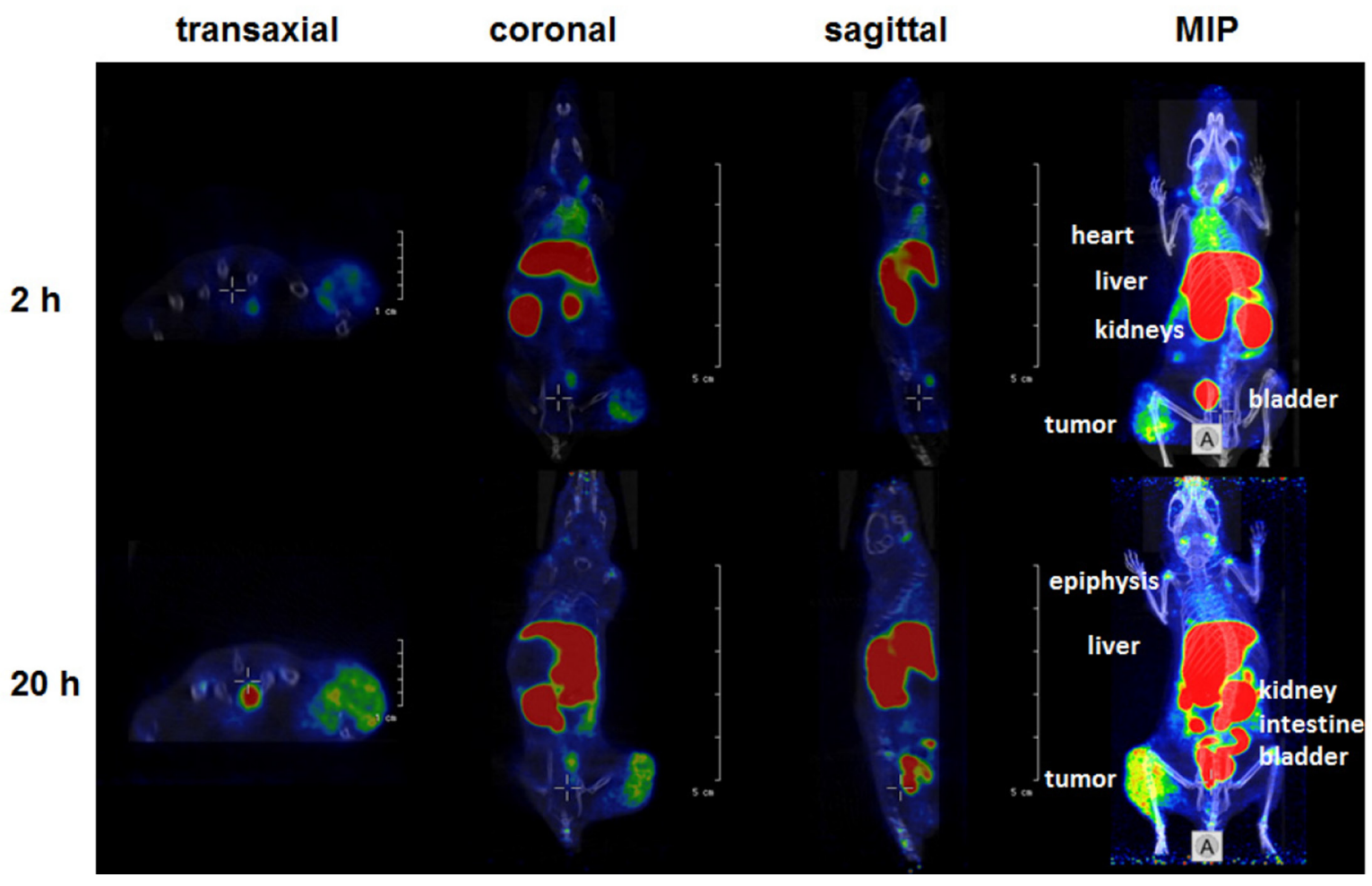

Figure 12: Small animal PET/CT. Orthogonal sections (transaxial, coronal, sagittal) scaled to visualize the tumor or maximum intensity projections (MIP) of a selected A431-Luc tumor bearing mouse at $2 \mathrm{~h}$ or $20 \mathrm{~h}$ after single intravenous injection of the $\left.{ }^{64} \mathrm{Cu}\right] \mathrm{Cu}-$ $\alpha$-EGFR-EGFR-NODAGA TM complex. Note: The $\left[{ }^{64} \mathrm{Cu}\right] \mathrm{Cu}-\alpha$-EGFR-EGFR-NODAGA TM complex further accumulates at the tumor site between $2 \mathrm{~h}$ and $20 \mathrm{~h}$ after injection (see also Figure 13B).
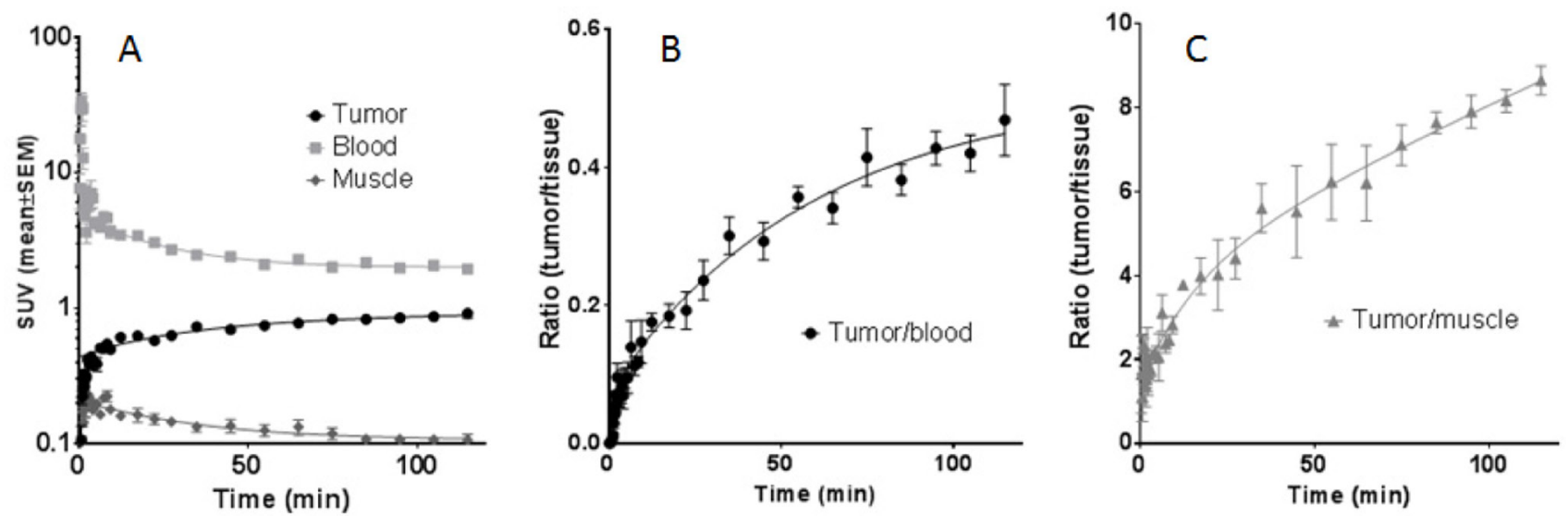

Figure 13: Time-activity curves (TAC) of regions of interest (ROI). The TAC curves are derived from PET studies of four A431-Luc tumor bearing mice after injection of the $\left[{ }^{64} \mathrm{Cu}\right] \mathrm{Cu}-\alpha$-EGFR-EGFR-NODAGA TM complex as indicated. (A) TAC representing primarily the tumor, blood, and muscle activity concentration $\left(\mathrm{SUV}_{\text {mean }}\right)$. (B), (C) TAC of the tumor ratios to blood and muscle, respectively, supporting the increasing image contrast even beyond $2 \mathrm{~h}$. 
EGFR phosphorylation. We only see a slight blocking effect at a concentration of the bivalent TM that occurs at around $10^{5}$ times the $\mathrm{EC}_{100}$ concentration requested for retargeting of UniCAR $\mathrm{T}$ cells. Consequently, such an unrealistic high TM concentration should never be reached under retargeting conditions in a patient and we therefore do not expect any interference of our TMs with EGFR signaling.

As for all previously described UniCAR/TM combinations, induction of tumor cell eradication via the UniCAR system was also strictly dependent on the presence of the novel bivalent $\alpha$-EGFR-EGFR TM. Not unexpected, as also seen in all of our previous retargeting studies the degree of tumor cell lysis varied in a wide range depending on the chosen $\mathrm{T}$ cell donor.

Due to raising the number of binding sites, the resulting bivalent $\alpha$-EGFR-EGFR TM shows (i) an increased apparent avidity in comparison to the affinity of the monovalent one, (ii) an improved killing efficacy and capability in vitro and in vivo, (iii) increased cytokine release of pro-inflammatory cytokines IFN- $\gamma$ and TNF as well as growth-promoting cytokine IL-2 and (iv) an improved PET imaging contrast.

Obviously, improving the avidity of the $\alpha$-EGFR TM increases the targeting capability: While the monovalent $\alpha$-EGFR TM strongly binds only to tumor cells expressing high levels of EGFR, the bivalent $\alpha$-EGFR-EGFR TM is able to efficiently bind to tumor cells with high, intermediate or even low EGFR surface expression levels. In line with these binding data, the monovalent $\alpha$-EGFR TM stimulates UniCAR T cells only to attack tumor cells expressing high levels of EGFR, while the bivalent $\alpha$-EGFR-EGFR TM engages UniCAR $\mathrm{T}$ cells even for an efficient lysis of cancer cells expressing low levels of EGFR. Nevertheless, it does not induce killing of MDA-MB-435S cells, whose number of EGFR molecules per cell is similar to healthy cells [44]. Hence, the risk for destruction of healthy tissues seems to be low.

As demonstrated by the TM titration experiments, 250-fold lower concentrations of the bivalent TM were able to activate UniCAR-armed $\mathrm{T}$ cells for tumor cell killing compared to the monovalent $\alpha$-EGFR TM. Consequently, the three-fold increase of avidity shifted $\mathrm{EC}_{50}$ values from the nano- to the picomolar range.

In agreement with the improved $\mathrm{EC}_{50}$ value of the bivalent $\alpha$-EGFR-EGFR TM, we could observe an increased anti-tumor effect in experimental mice. In our previous study, it was proven that the monovalent TM is able to mediate anti-tumor effects in a MRD mouse model [23]. Lowering the applied concentration of the monovalent construct ten times, resulted in loss of its functionality. On the contrary, under these limiting conditions the bivalent $\alpha$-EGFR-EGFR TM is still capable of activating UniCAR $\mathrm{T}$ cells for tumor cell killing. Consequently, the application of the bivalent $\alpha$-EGFREGFR TM in combination with the UniCAR system is
A

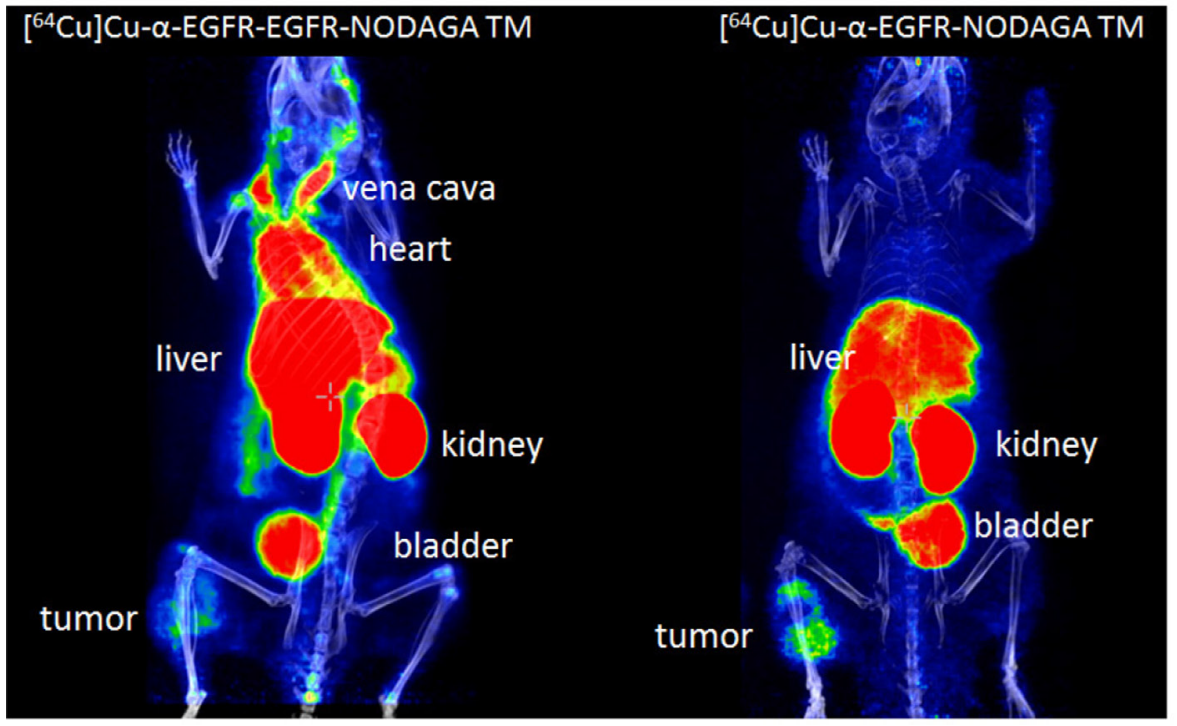

B

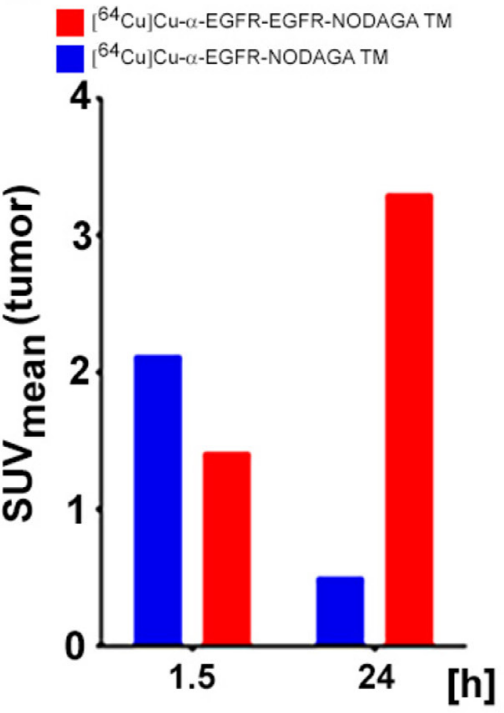

Figure 14: Small animal PET analysis of selected A431-Luc tumor bearing mice after single intravenous injection of the $\left[{ }^{64} \mathbf{C u}\right] \mathbf{C u}-\alpha$-EGFR-EGFR-NODAGA TM- or the $\left[{ }^{64} \mathbf{C u}\right] \mathbf{C u}-\alpha$-EGFR-NODAGA TM complex. (A) PET/CT scan scaled to maximum intensity projection at $2 \mathrm{~h}$ after injection of the $\left[{ }^{64} \mathrm{Cu}\right] \mathrm{Cu}-\alpha$-EGFR-EGFR-NODAGA TM complex (left panel) or the $\left[{ }^{64} \mathrm{Cu}\right]$ $\mathrm{Cu}-\alpha$-EGFR-NODAGA TM complex (right panel). Note: At this time point the $\left[{ }^{64} \mathrm{Cu}\right] \mathrm{Cu}-\alpha$-EGFR-EGFR-NODAGA TM complex can still be detected in the blood (heart) (left panel). In contrast, the $\left[{ }^{64} \mathrm{Cu}\right] \mathrm{Cu}-\alpha$-EGFR-NODAGA TM complex can hardly be detected in the blood (right panel). (B) The $\left[{ }^{64} \mathrm{Cu}\right] \mathrm{Cu}-\alpha$-EGFR-EGFR-NODAGA TM complex has not reached the maximum concentration in the tumor at $1.5 \mathrm{~h}$ after injection. The concentration can further increase in the tumor during the following $24 \mathrm{~h}$ (red bars). In contrast, the $\left[{ }^{64} \mathrm{Cu}\right] \mathrm{Cu}-\alpha-\mathrm{EGFR}-$ NODAGA TM complex has already reached the maximum concentration in the tumor during the first $1.5 \mathrm{~h}$ after injection and thus the concentration in the tumor decreases during the following $24 \mathrm{~h}$ (blue bars). 
favorable with regard to its therapeutic effects at low TM concentrations and low levels of target expression but at the risk of an increased cytokine release.

As recently published [23], the monovalent $\alpha$-EGFR $\mathrm{TM}$ is mainly eliminated via the kidneys. In contrast, the bivalent $\alpha$-EGFR-EGFR TM is eliminated via both, kidneys and liver. The altered elimination in combination with the improved avidity of the bivalent TM finally leads to an enhanced enrichment at the tumor site and thereby to an improved imaging contrast. Thus, the bivalent $\alpha$-EGFR-EGFR TM gains favorable targeting and imaging properties at the cost of an enhanced risk of cytokine release.

In summary, the here presented data show that UniCAR T cell-mediated tumor cell killing not solely depends on the affinity between the UniCAR and the UniCAR epitope of TMs but also on the affinity of the TM to the respective TAA as well as on the density of the TAA on the tumor cells. Below a certain TM affinity or tumor antigen density redirected UniCAR-armed T cells will only induce suboptimal or even no cell lysis. On the one hand, this could be favorable to spare healthy tissues expressing levels of the TAA below this threshold. On the other hand, tumor cells which express the target at low levels could be able to escape killing. To circumvent the escape of such low target antigen expressing tumor cell variants, enhancing the affinity with e.g. bivalent or combinatorial TMs represents an attractive strategy. However, such enhanced TMs may show an enhanced risk for CRS. Thus, a two-step UniCAR therapy could be favorable: A UniCAR-based therapy may be started using a small TM such as the monovalent $\alpha$-EGFR TM that may have a reduced risk of CRS and can rapidly be turned off in case severe CRS and/or tumor lysis syndrome occurs. Once the major tumor burden has been destroyed and the risk of these side effects are low, UniCAR-modified T cells may be armed with the more risky TM such as the $\alpha$-EGFR-EGFR TM which, however, allows the killing of tumor cells expressing low levels of the TAA.

\section{MATERIALS AND METHODS}

\section{Cell lines}

The epidermoid carcinoma cell line A431, the squamous cell carcinoma cell line $\mathrm{FaDu}$, the breast cancer cell line MDA-MB-435S as well as the CHO cell line were purchased from American Type Culture Collection and have not been further authenticated. The recombinant firefly luciferase-expressing target cell line A431-Luc and the recombinant PSCA-expressing cell line PC3-PSCA were generated via lentiviral transduction as described previously [45]. The CHO and the PC3-PSCA cell lines were cultured in complete RPMI 1640 medium [45]. FaDu cells and MDA-MB-435S cells were kept in complete DMEM medium [45] whereas the A431 and the
A431-Luc carcinoma cell lines were grown in complete DMEM medium supplemented with $1 \mathrm{mM}$ sodium pyruvate (Biochrom GmbH, Berlin, Germany). All cells were maintained at $37^{\circ} \mathrm{C}$ in a humidified atmosphere of $5 \% \mathrm{CO}_{2}$.

\section{Construction, expression and purification of recombinant antibodies}

Cloning of the monovalent $\alpha$-EGFR TM into the lentiviral vector p6NST50, transduction of $\mathrm{CHO}$ wt cells, Ab purification and analysis (SDS-PAGE, immunoblotting) were described previously [23]. The novel bivalent $\alpha$-EGFR-EGFR TM is based on a camelid $\mathrm{Nb}$ derived from the $\alpha$-EGFR Ab clone 7C12 [43]. In a first step, the synthesized gene NheI- $\alpha$-EGFR Nb-E5B9$\alpha$-EGFR $\mathrm{Nb}-\mathrm{Mss} \mathrm{I}$ was purchased from the company Eurofins Genomics (Ebersberg, Germany). To enable eukaryotic expression the open reading frame of the novel bivalent TM was cloned into the lentiviral vector p6NST50 as described previously [23], resulting in the vector p6NST50 $\alpha$-EGFR-EGFR TM. After transducing the vector into $\overline{\mathrm{CHO}}$ wt cells [46] the stably expressed TM was purified via Ni-NTA column $[45,47,48]$ and subsequently analyzed by SDS-PAGE and immunoblotting as published before [46, 48, 49].

\section{High-performance liquid chromatography}

For determination of the molecular weight and purity level of the purified $\alpha$-EGFR TM, $\alpha$-EGFREGFR TM and CHO wt supernatant, size exclusion highperformance liquid chromatography (SE-HPLC) was executed as described previously [23]. Therefore, a $15 \mu 1$ sample containing $15 \mu \mathrm{g}$ of the respective TM or $15 \mu \mathrm{l}$ of $\mathrm{CHO}$ wt supernatant were applied into the HPLC system.

\section{Activation and inhibition of EGFR signaling by Nb-based TMs}

In order to investigate the effects of EGFR-specific TMs on EGFR signaling, phosphorylation of the receptor was analyzed on the basis of a method published by Roovers et al. [50]. In brief, 1 x $10^{5}$ A431 tumor cells were cultured overnight in complete DMEM medium containing $0.1 \%$ FCS (Biochrom $\mathrm{GmbH}$ ). The next day, cells were washed and incubated in the same medium containing 1\% BSA and either 8 nM EGF (Gibco BRL, Eggenstein, Germany) or $1000 \mathrm{nM} \alpha$-EGFR TM or $1000 \mathrm{nM} \alpha$-EGFR-EGFR TM. After $15 \mathrm{~min}$ at $37^{\circ} \mathrm{C}$, cells were placed on ice and harvested by scraping them off the plate in $50 \mu 1$ RIPA buffer and $50 \mu 12 \times$ Laemmli protein sample buffer. A431 cells were further lysed by using a QIAshredder homogenizer (Qiagen $\mathrm{GmbH}$, Hilden, Germany) and by boiling the resulting lysate at $95^{\circ} \mathrm{C}$. Analysis of proteins was performed by 
SDS-PAGE with subsequent immunoblotting as already published [46, 48, 49]. Phosphorylated EGFR (pEGFR) was detected by a mouse $\alpha$-pEGFR (tyrosine 1068) mAb (Cell Signaling Technology, Danvers, MA, USA) and an alkaline phosphatase (AP)-conjugated $\alpha$-mouse IgG (Dianova, Hamburg, Germany). Additionally, $\beta$-tubulin served as loading control. Therefore, the same blot was stained against $\beta$-tubulin using a monoclonal $\beta$-tubulin $\mathrm{mAb}$ (Thermofisher, Dreieich, Germany). In addition to agonistic effects, the potential of Nb-based TMs to inhibit EGF-induced signaling was investigated. For this purpose, A431 cells were incubated with a mixture of EGF $(8 \mathrm{nM})$ and decreasing amounts of the respective TM (1000 nM, $100 \mathrm{nM}, 10 \mathrm{nM}, 1 \mathrm{nM})$. Afterwards, phosphorylation of EGFR was detected by immunoblotting.

\section{Flow cytometry analysis}

To determine the expression level of EGFR on MDA-MB-435S, PC3-PSCA, FaDu and A431 cell lines, the cells were stained with the mouse $\alpha$-EGFR IgG1 mAb (clone AY13; BioLegend, Fell, Germany). Quantification was performed using the QIFIKIT ${ }^{\circledR}$ (Agilent Technologies, Böblingen, Germany) and the included fluorochromelabeled $\alpha$-mouse IgG mAb according to the manufacturer's instructions. Binding properties of the novel $\alpha$-EGFREGFR TM or the monovalent $\alpha$-EGFR TM to different tumor cell lines was assessed by immunofluorescent staining as described before [45, 51]. As secondary $\mathrm{Ab}$ the mouse $\alpha$-E5B9 $\operatorname{IgG} 2 \mathrm{a} A \mathrm{~b}$ and as tertiary $\mathrm{Ab}$ a Pacific Blue ${ }^{\mathrm{TM}}$-conjugated $\alpha$-mouse-IgG (Fc $\gamma$ ) $\mathrm{Ab}$ (Life Technologies, Darmstadt, Germany) was used. Flow cytometry was performed with the MACSQuant ${ }^{\mathbb{B}}$ Analyzer and the MACSQuantify ${ }^{\circledR}$ software (Miltenyi Biotec $\mathrm{GmbH}$, Bergisch Gladbach, Germany). $\mathrm{K}_{\mathrm{d}}$ values were calculated as described [23].

\section{Isolation and lentiviral transduction of human $T$ cells}

Primary human T cells were isolated from peripheral blood mononuclear cells (PBMCs) out of buffy coats obtained from the German Red Cross (Dresden, Germany) with consent of the donors. The isolation steps and following cultivation of T cells in complete RPMI 1640 medium supplemented with $200 \mathrm{U} / \mathrm{ml} \mathrm{IL-2} \mathrm{(Proleukin}{ }^{\circledR} \mathrm{S}$, Novartis Pharmaceuticals, Horsham, UK), $5 \mathrm{ng} / \mathrm{ml} \mathrm{IL-7} \mathrm{and}$ 5 ng/ml IL-15 (ImmunoTools, Friesoythe, Germany) were performed as described elsewhere $[45,46]$. Subsequently, $\mathrm{T}$ cells were transduced with the lentiviral vector encoding either the EGFP marker protein (vector control), the UniCAR construct containing a dual CD28/CD3 $\zeta$ signaling

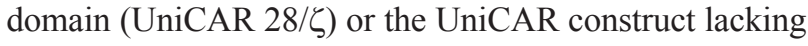
this domain (UniCAR stop) [22]. Production of lentiviral particles and transduction of human $\mathrm{T}$ cells was carried out as described previously [24, 52].

\section{Cytotoxicity assay}

To analyze the TM-mediated killing of tumor cells standard chromium release assays were performed as published before [e.g. 45].

\section{Cytokine-release assay}

For determination of IFN- $\gamma$, TNF and IL-2 concentrations in cell-free supernatants enzyme-linked immunosorbent assay (ELISA) was performed as described previously [45]. Therefore, $48 \mathrm{~h}$ after start of co-cultivation supernatants were collected and analyzed using OptEIA ${ }^{\text {TM }}$ Human IFN- $\gamma$, OptEIA ${ }^{\text {TM }}$ Human TNF and OptEIA ${ }^{\mathrm{TM}}$ Human IL-2 ELISA Kits (BD Biosciences, Heidelberg, Germany) according to the manufacturer's instructions.

\section{Radiolabeling}

The production of ${ }^{64} \mathrm{Cu}$ was performed at Cyclone(R) 18/9 (Helmholtz-Zentrum Dresden-Rossendorf) in a ${ }^{64} \mathrm{Ni}(\mathrm{p}, \mathrm{n}){ }^{64} \mathrm{Cu}$ nuclear reaction with specific activities of $150-250 \mathrm{GBq} / \mathrm{mmol} \mathrm{Cu}$ diluted in $\mathrm{HCl}(10 \mathrm{mM})$. For radiolabeling of the respective $\mathrm{TM}$ with ${ }^{64} \mathrm{Cu}$, the $\mathrm{pH}$ of the ${ }^{64} \mathrm{Cu}$ solution was adjusted to $\mathrm{pH} 5.2$ using $\mathrm{NH}_{4} \mathrm{OH}$ and $1.6 \mathrm{nmol}$ of the respective TM were added. The respective mixtures were shaken at $37^{\circ} \mathrm{C}$ for $30 \mathrm{~min}$. Then $1 \mu \mathrm{mol}$ EDTA was added and the radiolabeled TM was separated by spin filtration with PBS. The labeling process was monitored using instant thin-layer chromatography (ITLC). After chelating, the reaction mixture was supplemented with EDTA, and the radiolabeling efficiency was determined using both ITLC and size-exclusion high-performance liquid chromatography (SE-HPLC). SDS-PAGE of the labeled conjugates, followed by silver staining and autoradiography was performed to further evaluate the TM-specific conjugation.

\section{Optical imaging, small animal PET imaging and biodistribution analysis of tumor xenograft models}

Female NMRI-Foxn $1^{\text {nu}} /$ Foxn $1^{\text {nu }}$ mice (JANVIER LABS, St. Berthevin, France) were kept at the HelmholtzZentrum Dresden-Rossendorf (HZDR) according to the guidelines of German Regulations for Animal Welfare. All animal experiments have been approved by the Landesdirektion Dresden (24-9165.40-4, 24.9168.214/2004-1).

For optical imaging of anti-tumor effects, $1.5 \times$ $10^{6} \mathrm{~A} 431$ cells were investigated alone or together with $1.5 \times 10^{6}$ human UniCAR $28 / \zeta$-armed $\mathrm{T}$ cells in the presence or absence of $600 \mathrm{pmol}$ of the $\alpha$-EGFR TM or the $\alpha$-EGFR-EGFR TM. Cell mixtures (100 $\mu \mathrm{l} /$ mouse) were subcutaneously injected into the right tight of eightweek-old experimental mice. To analyze the tumor growth 
general anesthesia was induced as published recently [23, 25]. After i.p. injection of luciferin $(200 \mu \mathrm{l}, 15 \mathrm{mg} / \mathrm{ml})$ (Thermofisher, Dreieich, Germany) luminescence imaging and X-ray photography were performed using a dedicated small animal multimodal imaging system (Xtreme, Bruker, Germany) as described previously [24].

For PET imaging, immunodeficient mice, aged 5-8 weeks, were subcutaneously injected in the right hind flank with 1 x $10^{6}$ A431-Luc cells. After six to eight weeks, tumor size was measured as already described [23]. For pharmacological analyses, animals with $100-500 \mathrm{~mm}^{3}$ tumors were selected. After labeling of respective $\mathrm{Ab}$ constructs with ${ }^{64} \mathrm{Cu}[23,25]$, approximately $3.7 \mathrm{MBq}\left[{ }^{64} \mathrm{Cu}\right] \mathrm{Cu}-\alpha$-EGFRNODAGA TM or $\left[{ }^{64} \mathrm{Cu}\right] \mathrm{Cu}-\alpha$-EGFR-EGFR-NODAGA $\mathrm{TM}$ were intravenously inoculated into a lateral tail vein of four A431-Luc tumor-bearing NMRI ${ }^{\text {nu/nu }}$ mice. Dynamic PET scans were acquired over 120 min using a small animal PET/CT scanner (NanoPET/CT, Mediso). In addition, a static scan was obtained $20 \mathrm{~h}$ after injection. Visualization was performed via InterView (Mediso) and ROVER software $(\mathrm{ABX} \mathrm{GmbH})$. After quantification, data were expressed as standardized uptake value (SUV), representing the activity concentration normalized to the body weight. SUV is defined as tissue concentration $(\mathrm{MBq} / \mathrm{ml}) \mathrm{x}$ body weight $(\mathrm{g}) /$ injected dose (MBq). The corresponding time activity curves (TAC) are based on the average \pm SEM.

To analyze the tumor targeting and the biodistribution of the ${ }^{64} \mathrm{Cu}$-radiolabeled mono- and bivalent TM, four A431-Luc tumor-bearing NMRI ${ }^{\mathrm{nu}}$ ${ }^{\text {nu }}$ mice were intravenously injected with approximately $0.5 \mathrm{MBq}$ of the respective construct. After $2 \mathrm{~h}$ incubation time, mice were killed and selected organs, tissues as well as blood were taken and measured as already described [23]. Quantitative data were expressed as SUV.

\section{Statistical analysis}

Statistical analysis of multiple experiments was performed with GraphPad Prism software version 6.0 (GraphPad Software Inc., La Jolla, CA, USA) using one-way ANOVA with posthoc Bonferroni Multiple Comparison or Tukeys test.

\section{Author contributions}

S.A., C.A., R.B. and M.B. designed experiments, S.A., N.B., and R.B. performed experiments and evaluated data, M.S., J.P., J.S. and M.B. provided critical materials, C.A., S.K. and A.F. discussed the data and provided critical suggestions, S.A., C.A., S.K., R.B. and M.B. analyzed and interpreted data, M.B. invented the UniCAR technology, S.A., C.A. and M.B. wrote the manuscript.

\section{ACKNOWLEDGMENTS}

The authors thank Martin Walther, Ulrike Gesche and Christian Jentschel for the preparation of the ${ }^{64} \mathrm{Cu}$ - isotope solutions, Andrea Suhr for her technical assistance with radiolabeling and Regina Herrlich for assistance in the animal experiments. We thank Julia Lagler for technical assistance.

\section{CONFLICTS OF INTEREST}

$\mathrm{MB}$ has filed patent applications related to the UniCAR platform.

\section{FUNDING}

This study was supported by a grant provided to M.B. by the DKTK.

\section{REFERENCES}

1. Modjtahedi H, Dean C. The receptor for EGF and its ligands - expression, prognostic value and target for therapy in cancer (review). Int J Oncol. 1994; 4:277-96. https://doi. org/10.3892/ijo.4.2.277.

2. Herbst RS, Langer CJ. Epidermal growth factor receptors as a target for cancer treatment: the emerging role of IMCC225 in the treatment of lung and head and neck cancers. Semin Oncol. 2002; 29:27-36. https://doi.org/10.1053/ sonc.2002.31525.

3. Dutta PR, Maity A. Cellular responses to EGFR inhibitors and their relevance to cancer therapy. Cancer Lett. 2007; 254:165-77. https://doi.org/10.1016/j.canlet.2007.02.006.

4. Herbst RS. Review of epidermal growth factor receptor biology. Int J Radiat Oncol Biol Phys. 2004; 59:21-6. https://doi.org/10.1016/j.ijrobp.2003.11.041.

5. Partanen AM. Epidermal growth factor and transforming growth factor-alpha in the development of epithelialmesenchymal organs of the mouse. Curr Top Dev Biol. 1990; 24:31-55. https://doi.org/10.1016/ S0070-2153(08)60083-6.

6. Adamson ED. Developmental activities of the epidermal growth factor receptor. Curr Top Dev Biol. 1990; 24:1-29. https://doi.org/10.1016/S0070-2153(08)60082-4.

7. Song J, Lee S, Hong JP, Chang SE, Choe H, Choi J. Epidermal growth factor competes with EGF receptor inhibitors to induce cell death in EGFR-overexpressing tumor cells. Cancer Lett. 2009; 283:135-42. https://doi. org/10.1016/j.canlet.2009.03.034.

8. Lynch TJ, Bell DW, Sordella R, Gurubhagavatula S, Okimoto RA, Brannigan BW, Harris PL, Haserlat SM, Supko JG, Haluska FG, Louis DN, Christiani DC, Settleman J, et al. Activating mutations in the epidermal growth factor receptor underlying responsiveness of nonsmall-cell lung cancer to gefitinib. N Engl J Med. 2004; 350:2129-39. https://doi.org/10.1056/NEJMoa040938.

9. Wong AJ, Ruppert JM, Bigner $\mathrm{SH}$, Grzeschik $\mathrm{CH}$, Humphrey PA, Bigner DS, Vogelstein B. Structural alterations of the epidermal growth factor receptor gene 
in human gliomas. Proc Natl Acad Sci U S A. 1992; 89:2965-9.

10. Nicholson RI, Gee JM, Harper ME. EGFR and cancer prognosis. Eur J Cancer. 2001; 37:9-15. https://doi. org/10.1016/S0959-8049(01)00231-3.

11. Navolanic PM, Steelman LS, McCubrey JA. EGFR family signaling and its association with breast cancer development and resistance to chemotherapy (review). Int J Oncol. 2003; 22:237-52. https://doi.org/10.3892/ijo.22.2.237.

12. Bowers G, Reardon D, Hewitt T, Dent P, Mikkelsen RB, Valerie K, Lammering G, Amir C, Schmidt-Ullrich RK. The relative role of ErbB1-4 receptor tyrosine kinases in radiation signal transduction responses of human carcinoma cells. Oncogene. 2001; 20:1388-97. https://doi.org/10.1038/ sj.onc. 1204255 .

13. Lammering G, Hewit TH, Hawkins WT, Contessa JN, Reardon DB, Lin PS, Valerie K, Dent P, Mikkelsen RB, Schmidt-Ullrich RK. Epidermal growth factor receptor as a genetic therapy target for carcinoma cell radiosensitization. J Natl Cancer Inst. 2001; 93:921-9. https://doi.org/10.1093/ jnci/93.12.921.

14. Milas L, Mason KA, Ang KK. Epidermal growth factor receptor and its inhibition in radiotherapy: in vivo findings. Int J Radiat Biol. 2003; 79:539-45. https://doi.org/10.1080 /0955300031000114747.

15. Alorabi M, Shonka NA, Ganti AK. EGFR monoclonal antibodies in locally advanced head and neck squamous cell carcinoma: What is their current role? Crit Rev Oncol Hematol. 2016; 99:170-9. https://doi.org/10.1016/j. critrevonc.2015.12.006.

16. Köhler J, Schuler M. Afatinib, erlotinib and gefitinib in the first-line therapy of EGFR mutation-positive lung adenocarcinoma: a review. Oncol Res Treat. 2013; 36:510-8. https://doi.org/10.1159/000354627.

17. Han W, Lo HW. Landscape of EGFR signaling network in human cancers: biology and therapeutic response in relation to receptor subcellular locations. Canc Lett. 2012; 318:12434. https://doi.org/10.1016/j.canlet.2012.01.011.

18. Chiavenna SM, Jaworski JP, Vendrell A. State of the art in anti-cancer mAbs. J Biomed Sci. 2017; 24:15. https://doi. org/10.1186/s12929-016-0311-y.

19. Yano S, Kondo K, Yamaguchi M, Richmond G, Hutchison M, Wakeling A, Averbuch S, Wadsworth P. Distribution and function of EGFR in human tissue and the effect of EGFR tyrosine kinase inhibition. Anticancer Res. 2003; 23:3639-50.

20. Lenz HJ. Anti-EGFR mechanism of action: antitumor effect and underlying cause of adverse events. Oncology (Williston Park). 2006; 20:5-13.

21. Koristka S, Cartellieri M, Feldmann A, Arndt C, Loff S, Michalk I, Aliperta R, von Bonin M, Bornhäuser M, Ehninger A, Ehninger G, Bachmann M. Flexible antigenspecific redirection of human regulatory $\mathrm{T}$ cells via a novel universal chimeric antigen receptor system. Blood. 2014; 124:3494.

22. Cartellieri M, Feldmann A, Koristka S, Arndt C, Loff S, Ehninger A, von Bonin M, Bejestani EP, Ehninger G, Bachmann MP. Switching CAR T cells on and off: a novel modular platform for retargeting of T cells to AML blasts. Blood Cancer J. 2016; 6:e458. https://doi.org/10.1038/ bcj.2016.61.

23. Albert S, Arndt C, Feldmann A, Bergmann R, Bachmann D, Koristka S, Ludwig F, Ziller-Walter P, Kegler A, Gärtner S, Schmitz M, Ehninger A, Cartellieri M, et al. A novel nanobody-based target module for retargeting of $\mathrm{T}$ lymphocytes to EGFR-expressing cancer cells via the modular UniCAR platform. Oncoimmunology. 2017; 6:e1287246. https://doi.org/10.1080/21624 02X.2017.1287246. eCollection 2017.

24. Feldmann A, Arndt C, Bergmann R, Loff S, Cartellieri M, Bachmann D, Aliperta R, Hetzenecker M, Ludwig F, Albert S, Ziller-Walter P, Kegler A, Koristka S, et al. Retargeting of T lymphocytes to PSCA- or PSMA positive prostate cancer cells using the novel modular chimeric antigen receptor platform technology "UniCAR". Oncotarget. 2017; 8:31368-85. https://doi.org/10.18632/oncotarget.15572.

25. Mitwasi N, Feldmann A, Bergmann R, Berndt N, Arndt C, Kosistka S, Kegler A, Jureczek J, Hoffmann A, Ehninger A, Cartellieri M, Albert S, Rossig C, et al. Development of novel target modules for retargeting of UniCAR T cells to GD2-positive tumor cells. Oncotarget. 2017; 8:108584-8603. https://doi.org/10.18632/oncotarget.21017.

26. Bachmann D, Aliperta R, Bergmann R, Feldmann A, Koristka S, Arndt C, Loff S, Welzel P, Albert S, Kegler A, Ehninger A, Cartellieri M, Ehninger G, et al. Retargeting of UniCAR T cells with an in vivo synthesized target module directed against CD19 positive tumor cells. Oncotarget. 2017; 9:7487-7500. https://doi.org/10.18632/oncotarget.23556.

27. Pishali Bejestani E, Cartellieri M, Bergmann R, Ehninger A, Loff S, Kramer M, Spehr J, Dietrich A, Feldmann A, Albert S, Wermke M, Baumann M, Krause M, et al. Characterization of a switchable chimeric antigen receptor platform in a pre-clinical solid tumor model. Oncoimmunology. 2017; 6:e1342909. https://doi.org/10.1 080/2162402X.2017.1342909.

28. Cartellieri M, Bachmann M, Feldmann A, Bippes C, Stamova S, Wehner R, Temme A, Schmitz M. Chimeric antigen receptor-engineered $\mathrm{T}$ cells for immunotherapy of cancer. J Biomed Biotechnol. 2010; 2010:956304. https:// doi.org/10.1155/2010/956304.

29. Liu L, Sun M, Wang Z. Adoptive T-cell therapy of B-cell malignancies: conventional and physiological chimeric antigen receptors. Cancer Lett. 2012; 316:1-5. https://doi. org/10.1016/j.canlet.2011.10.027.

30. Xu XJ, Tang YM. Cytokine release syndrome in cancer immunotherapy with chimeric antigen receptor engineered $\mathrm{T}$ cells. Cancer Lett. 2013; 343:172-8. https://doi. org/10.1016/j.canlet.2013.10.004. 
31. Maude SL, Frey N, Shaw PA, Aplenc R, Barrett DM, Bunin NJ, Chew A, Gonzalez VE, Zheng Z, Lacey SF, Mahnke YD, Melenhorst JJ, Rheingold SR, et al. Chimeric antigen receptor $\mathrm{T}$ cells for sustained remissions in leukemia. $\mathrm{N}$ Engl J Med. 2014; 371:1507-17. https://doi.org/10.1056/ NEJMoa1407222.

32. Brudno JN, Kochenderfer JN. Toxicities of chimeric antigen receptor $\mathrm{T}$ cells: recognition and management. Blood. 2016; 127:3321-30. https://doi.org/10.1182/ blood-2016-04-703751.

33. Lamers $\mathrm{CH}$, Sleijfer $\mathrm{S}$, van Steenbergen $\mathrm{S}$, van Elzakker P, van Krimpen B, Groot C, Vulto A, den Bakker M, Oosterwijk E, Debets R, Gratama JW. Treatment of metastatic renal cell carcinoma with CAIX CARengineered T cells: clinical evaluation and management of on-target toxicity. Mol Ther. 2013; 21:904-12. https://doi. org/10.1038/mt.2013.17.

34. Davila ML, Riviere I, Wang X, Bartido S, Park J, Curran K, Chung SS, Stefanski J, Borquez-Ojeda O, Olszewska M, Qu J, Wasielewska T, He Q, et al. Efficacy and toxicity management of 19-28z CAR T cell therapy in B cell acute lymphoblastic leukemia. Sci Transl Med. 2015; 6:224ra25. https://doi.org/10.1126/scitranslmed.3008226.

35. Bonifant CL, Jackson HJ, Brentjens RJ, Curran KJ. Toxicity and management in CAR T-cell therapy. Mol Ther Oncolytics. 2016; 3:16011. https://doi.org/10.1038/ mto.2016.11.

36. Gainkam LOT, Huang L, Caveliers V, Keyaerts M, Hernot S, Vaneycken I, Vanhove C, Revets H, De Baetselier P, Lahoutte T. Comparison of the biodistribution and tumor targeting of two 99mTc-labeled anti-EGFR nanobodies in mice, using pinhole SPECT/micro-CT. J Nucl Med. 2008; 49:788-95. https://doi.org/10.2967/jnumed.107.048538.

37. Buday L, Downward J. Epidermal growth factor regulates p21ras through the formation of a complex of receptor, Grb2 adapter protein, and Sos nucleotide exchange factor. 1993; 73:611-20.

38. Ruella M, Kenderian SS. Next-generation chimeric antigen receptor T-cell therapy: going off the shelf. BioDrugs. 2017; 31:473-81. https://doi.org/10.1007/s40259-017-0247-0.

39. Golubovskaya V. CAR-T cell therapy: from the bench to the bedside. Cancers. 2017; 9:150. https://doi.org/10.3390/ cancers9110150.

40. Morgan RA, Yang JC, Kitano M, Dudley ME, Laurencot $\mathrm{CM}$, Rosenberg SA. Case report of a serious adverse event following the administration of $\mathrm{T}$ cells transduced with a chimeric antigen receptor recognizing ERBB2. Mol Ther. 2010; 18:843-51. https://doi.org/10.1038/mt.2010.24.

41. Heslop HE, Slobod KS, Pule MA, Hale GA, Rousseau A, Smith CA, Bollard CM, Liu H, Wu MF, Rochester RJ, Amrolia PJ, Hurwitz JL, Brenner MK, et al. Longterm outcome of EBV-specific T-cell infusions to prevent or treat EBV-related lymphoproliferative disease in transplant recipients. Blood. 2010; 115:925-35. https://doi. org/10.1182/blood-2009-08-239186.
42. Scholler J, Brady TL, Binder-Scholl G, Hwang WT, Plesa G, Hege KM, Vogel AN, Kalos M, Riley JL, Deeks SG, Mitsuyasu RT, Bernstein WB, Aronson NE, et al. Decadelong safety and function of retroviral-modified chimeric antigen receptor T cells. Sci Transl Med. 2012; 4:132ra53. https://doi.org/10.1126/scitranslmed.3003761.

43. Roovers RC, Vosjan MJ, Laermans T, el Khoulati R, de Bruin RC, Ferguson KM, Verkleij AJ, van Dongen GA, van Bergen en Henegouwen PM. A biparatopic antiEGFR nanobody efficiently inhibits solid tumour growth. Int J Cancer. 2011; 129:2013-24. https://doi.org/10.1002/ ijc. 26145 .

44. Sandoval MA, Sloat BR, Lansakara-P DS, Kumar A, Rodriguez BL, Kiguchi K, DiGiovanni J, Cui Z. EGFRtargeted stearoyl gemcitabine nanoparticles show enhanced anti-tumor activity. J Control Release. 2012; 157:287-96. https://doi.org/10.1016/j.jconrel.2011.08.015.

45. Feldmann A, Stamova S, Bippes CC, Bartsch H, Wehner R, Schmitz M, Temme A, Cartellieri M, Bachmann $\mathrm{M}$. Retargeting of $\mathrm{T}$ cells to prostate stem cell antigen expressing tumor cells: comparison of different antibody formats. Prostate. 2011; 71:998-1011. https://doi. org/10.1002/pros.21315.

46. Feldmann A, Arndt C, Töpfer K, Stamova S, Krone F, Cartellieri M, Koristka S, Michalk I, Lindemann D, Schmitz M, Temme A, Bornhäuser M, Ehninger G, et al. Novel humanized and highly efficient bispecific antibodies mediate killing of prostate stem cell antigenexpressing tumor cells by CD8+ and CD4+ T cells. J Immunol. 2012; 189:3249-59. https://doi.org/10.4049/ jimmunol.1200341.

47. Koristka S, Cartellieri M, Theil A, Feldmann A, Arndt C, Stamova S, Michalk I, Töpfer K, Temme A, Kretschmer K, Bornhäuser M, Ehninger G, Schmitz M, et al. Retargeting of human regulatory $\mathrm{T}$ cells by single-chain bispecific antibodies. J Immunol. 2012; 188:1551-8. https://doi. org/10.4049/jimmunol.1101760.

48. Koristka S, Cartellieri M, Arndt C, Bippes CC, Feldmann A, Michalk I, Wiefel K, Stamova S, Schmitz M, Ehninger G, Bornhäuser M, Bachmann M. Retargeting of regulatory $\mathrm{T}$ cells to surface-inducible autoantigen La/SS-B. J Autoimmun. 2013; 42:105-16. https://doi.org/10.1016/j. jaut.2013.01.002.

49. Arndt C, Koristka S, Feldmann A, Bartsch H, Bachmann M. Coomassie-Brilliant Blue staining of polyacrylamide gels. Methods Mol Biol. 2012; 869:465-9. https://doi. org/10.1007/978-1-61779-821-4_40.

50. Roovers RC, Laeremans T, Huang L, De Taeye S, Verkleij AJ, Revets H, de Haard HJ, van Bergen en Henegouwen PM. Efficient inhibition of EGFR signaling and of tumour growth by antagonistic anti-EGFR nanobodies. Cancer Immunol Immunother. 2007; 56:303-17. https://doi. org/10.1007/s00262-006-0180-4.

51. Arndt C, Feldmann A, Töpfer K, Koristka S, Cartellieri M, Temme A, Ehninger A, Ehninger G, Bachmann M. 
Redirection of CD4+ and CD8+ T lymphocytes via a novel antibody-based modular targeting system triggers efficient killing of PSCA+ prostate tumor cells. Prostate. 2014; 74:1347-58. https://doi.org/10.1002/pros.22851.

52. Cartellieri M, Koristka S, Arndt C, Feldmann A, Stamova S, von Bonin M, Töpfer K, Krüger T, Geib M, Michalk
I, Temme A, Bornhäuser M, Lindemann D, et al. A novel ex vivo isolation and expansion procedure for chimeric antigen receptor engrafted human T cells. PLoS One. 2014; 9:e93745. https://doi.org/10.1371/journal.pone.0093745. 